\title{
NEW DATES FROM ZVEJNIEKI BURIAL GROUND GRAVES WITH ANTHROPOMORPHIC AND ZOOMORPHIC FIGURINES
}

\author{
ILGA ZAGORSKA, JOHN MEADOWS, MARIUS IRŠE்NAS
}

\begin{abstract}
This article discusses the imagery of anthropomorphic and zoomorphic figurines which accompanied eleven burials in the Stone Age cemetery at Zvejnieki, Latvia. These burials date to the sixth, fifth and early-mid fourth millennia cal BC, according to radiocarbon dates of human remains from ten of the eleven burials, three of which were dated for this paper. The figurines are considered in terms of their characteristic formal qualities and their position within graves. Parallels are drawn with similar finds from elsewhere in the Baltic region. The imagery employed appears to be based on observations of nature, the fishing and hunting lifeways of these communities, and their beliefs concerning life after death, which were not apparently affected by the transitions from Mesolithic to Neolithic, and between Early Neolithic Narva culture and Middle Neolithic Typical Comb Ware Culture.
\end{abstract}

Key words: Zvejnieki, Stone age, Burial ground, Radiocarbon dating, Anthropomorphic and Zoomorphic figurines

DOI: http://dx.doi.org/10.15181/ab.v25i0.1833

\section{Introduction}

Zvejnieki burial ground, excavated in the 1960s and 70 s by Francis Zagorskis $(1987 ; 2004)$ and very intensively researched in recent years (Nilsson-Stutz et al. 2013; Meadows et al. 2016; 2018; Zagorska 2016; Tõrv et al. 2017), still offers the potential for new interpretations of the recovered archaeological material. This also applies to the artistic representations deposited as grave goods, including zoomorphic and anthropomorphic figurines.

The Zvejnieki archaeological complex - a burial ground and two adjacent settlement sites - was situated on a gravel ridge of glacial origin, formerly an island in palaeolake Burtnieks (Fig. 1). The initial dating of the burials was based on artefact typology, the areal distribution of the burials and changing burial practices. On this basis, two groups were distinguished: Mesolithic burials, on the highest part of the ridge, and Neolithic burials, in the area where an old farmhouse is now situated. In general, the conclusions drawn by the archaeologists have been confirmed by radiocarbon dating. At the same time the dating provide evidence of a more complicated picture and indicate the necessity of dating each separate burial, as the whole area served as a cemetery during all stages of the Mesolithic and Neolithic. The same applies to the graves containing anthropomorphic and zoomorphic figurines, because these figurines can't be dated independently and the other grave goods found with the figurines are not always chronologically sensitive (in contrast to other set- tings, where burials often have diagnostic pottery or metalwork).

The number of burials at Zvejnieki with figurines is small: there are only 14 pieces from 11 burials (out of a total 330 excavated burials). The sculptures found at Zvejnieki are made from various materials: mostly bone and antler, less commonly clay and stone. They represent birds, cervids, some aquatic animals, and humans (Zagorskis 1973; Butrimas 2000; Zagorska 2000; Iršènas 2000; 2006; 2010).

This material is now being investigated through renewed examination of excavation records, field drawings and photographs, supplemented by new radiocarbon dates.

The graves containing anthropomorphic and zoomorphic figurines are distributed in different areas of the burial ground, forming three groups: burials situated on the north-western slope of the gravel ridge (Fig. 1: I), burials located on the southern slope of the ridge (Fig. 1: II) and burials around the Zvejnieki farmstead, on the south-eastern slope of the ridge (Fig. 1: III). The first group represents mainly Late Mesolithic and Early Neolithic burials; the second consists mainly of Late Early Neolithic burials; and the third includes burials from the Middle Neolithic (Tables I, II).

The areal and typological division of the graves containing art objects is now supported, and also refined, by new radiocarbon dating of the burials. Of the 11 burials with figurines, 10 are dated by radiocarbon, but 1 is only dated typologically. 
Table I. Description of the dated Zvejnieki burials containing art objects (according to Ilga Zagorska)

\begin{tabular}{|c|c|c|c|c|c|c|c|c|}
\hline Grave & Sex & Position & Orientation & Ochre & Stones & Art representations & Other grave goods & Dating \\
\hline 74 & female & $\begin{array}{l}\text { extended } \\
\text { supine }\end{array}$ & SW - NE & intense & - & $\begin{array}{l}\text { bird figurine by } \\
\text { skull, wild boar tusk }\end{array}$ & $\begin{array}{l}43 \text { tooth-pendants - } \\
\text { elk, deer, wild boar, } \\
\text { grey seal }\end{array}$ & LM \\
\hline 100 & Infans II & $\begin{array}{l}\text { extended } \\
\text { supine }\end{array}$ & NE - SW & intense & $\begin{array}{l}\text { stone } \\
\text { package }\end{array}$ & $\begin{array}{l}\text { bird figurine-pendant } \\
\text { at the waist-line, } \\
\text { bone }\end{array}$ & $\begin{array}{l}72 \text { tooth-pendants- } \\
\text { wild boar, elk,red deer, } \\
\text { aurochs, wild horse }\end{array}$ & LM \\
\hline 57 & female & $\begin{array}{l}\text { extended } \\
\text { supine }\end{array}$ & NW - SE & intense & $\begin{array}{l}\text { stone } \\
\text { package }\end{array}$ & $\begin{array}{l}\text { staff of elk head by } \\
\text { left leg, bone }\end{array}$ & $\begin{array}{l}\text { bone spearhead, } \\
\text { stone axe, } 49 \text { tooth- } \\
\text { pendants(elk, red deer, } \\
\text { aurochs) }\end{array}$ & LM \\
\hline 121 & female & $\begin{array}{l}\text { extended } \\
\text { supine }\end{array}$ & $\mathrm{S}-\mathrm{N}$ & intense & - & $\begin{array}{l}\text { stone object on the } \\
\text { right side of pelvis }\end{array}$ & $\begin{array}{l}115 \text { tooth-pendants: } \\
\text { elk, wild boar, aurochs, } \\
\text { fox, otter, beaver, seal, } \\
\text { dog, bird }\end{array}$ & LM \\
\hline 162 & male & $\begin{array}{l}\text { extended } \\
\text { supine }\end{array}$ & $E-W$ & $\begin{array}{l}\text { partly } \\
\text { (by } \\
\text { skull) }\end{array}$ & - & $\begin{array}{l}\text { bird figurine under } \\
\text { pelvis, on right side, } \\
\text { bone }\end{array}$ & $\begin{array}{l}6 \text { tooth-pendants (elk, } \\
\text { aurochs) }\end{array}$ & EN \\
\hline 172 & infans I & $\begin{array}{l}\text { extended } \\
\text { (?) }\end{array}$ & SW - NE (?) & $\begin{array}{l}\text { small } \\
\text { amount }\end{array}$ & - & $\begin{array}{l}\text { human (female) } \\
\text { figurine, antler }\end{array}$ & - & EN (?) \\
\hline $271 \mathrm{a}$ & infans I & $?$ & SE - NW & weak & - & $\begin{array}{l}\text { staff, formed as } \\
\text { animal head, antler, } \\
\text { by legs }\end{array}$ & - & $\mathrm{MN}$ \\
\hline 228 & male & $\begin{array}{l}\text { extended } \\
\text { supine }\end{array}$ & $E-W$ & - & - & $\begin{array}{l}2 \text { bird figurines, } \\
2 \text { human head } \\
\text { depictions as } \\
\text { pendants under the } \\
\text { chin, bone }\end{array}$ & $\begin{array}{l}\text { bone arrowhead, string } \\
\text { of } 17 \text { amber buttons }\end{array}$ & $\mathrm{MN}$ \\
\hline 277 & male & $\begin{array}{l}\text { extended } \\
\text { supine } \\
\text { (collective } \\
\text { grave) }\end{array}$ & $W-E$ & intense & - & $\begin{array}{l}\text { staff of elk head by } \\
\text { feet, antler }\end{array}$ & $\begin{array}{l}2 \text { copper rings, amber } \\
\text { ring and bead, tooth- } \\
\text { pendants: marten, pig }\end{array}$ & $\mathrm{MN}$ \\
\hline 221 & female & $\begin{array}{l}\text { extended } \\
\text { supine } \\
\text { (collective } \\
\text { grave) }\end{array}$ & SE - NW & intense & - & $\begin{array}{l}\text { bird figurine, antler, } \\
\text { by left leg }\end{array}$ & $\begin{array}{l}65 \text { amber ornaments, } \\
2 \text { stone rings, flint } \\
\text { arrowhead, antler } \\
\text { objects, bone fish hook }\end{array}$ & $\mathrm{MN}$ \\
\hline 224 & infans I & $\begin{array}{l}\text { extended } \\
\text { supine, in } \\
\text { collective } \\
\text { grave by } \\
\text { interred } \\
\text { person } \\
\text { in grave } \\
225\end{array}$ & NW - SE & intense & - & $\begin{array}{l}\text { clay bent idol } \\
\text { between ribs }\end{array}$ & 2 small amber rings & $\mathrm{MN}$ \\
\hline
\end{tabular}

\section{Radiocarbon dating}

None of the osseous figurines from Zvejnieki has been dated directly, but seven of the eleven Zvejnieki burials with figurines were dated by AMS radiocarbon $\left({ }^{14} \mathrm{C}\right)$ dating in earlier studies (Zagorska, Larsson 1994; Zagorska 1997; Eriksson et al. 2003; see Table II), and this paper presents four new dates from three more graves, burials 74,100 and 271 . With the exception of the second new sample from burial 100, the dated material in each case was human bone, from an articulated skeleton, which cannot have been redeposited long after death. The figurines found in these graves, assuming that they were deposited together with the inhumated human, should be almost exactly contem- poraneous with the dates of the corresponding human bone samples.

Human ${ }^{14} \mathrm{C}$ ages at Zvejnieki are often misleadingly old, however, due to consumption of ${ }^{14} \mathrm{C}$-depleted aquatic species ('dietary reservoir effects'); it is therefore essential to use stable isotopes $\left(\delta^{13} \mathrm{C}, \delta^{15} \mathrm{~N}\right)$ to estimate the carbon contribution of aquatic species to human ${ }^{14} \mathrm{C}$ ages, and thus obtain a more accurate, if less precise, estimate of the calendar date of each burial (Meadows et al. 2016; 2018). Here, we test this approach by dating both a human bone from burial 100, and an associated pendant - the perforated tooth of a wild horse, whose diet is assumed to be fully terrestrial, and which should provide an accurate date for this burial. We use 


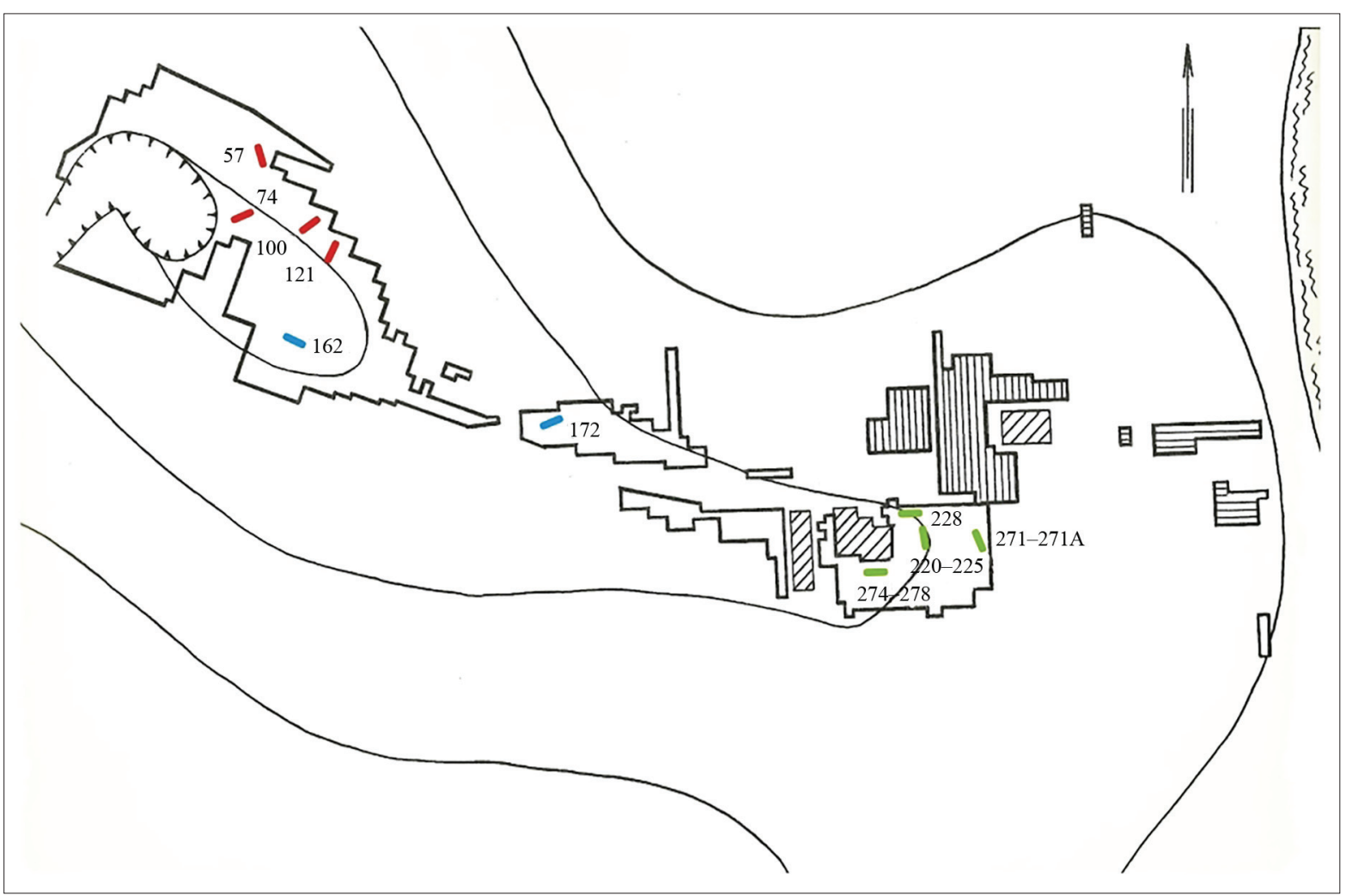

Fig. 1. General plan of Zvejnieki burial ground and settlement sites. I - red; II - blue; III - green; showing burials with artistic representations (after Zagorskis, 1987).

dietary reconstruction, based on stable isotopes, to correct the ${ }^{14} \mathrm{C}$ ages of eight of the other nine AMS-dated burials with figurines. The ninth case, burial 224, is part of a multiple burial (220-225), and is stratigraphically earlier than burial 221 , for which dietary reservoir correction is possible. Burial 224 was apparently contemporaneous with burial 225 , for which there is only a ${ }^{14} \mathrm{C}$ age, providing a maximum (terminus post quem) date for the death of that individual. As none of the stratigraphically earlier skeletons in the grave were disturbed by later inhumations, however, it is very likely that all six individuals (and their grave goods) are the same date as burial 221 .

The new samples were taken using a dental drill to abrade the surface layer of each bone/tooth, before cutting or drilling out the dating samples. To limit damage to the collection, sampling locations were carefully chosen to avoid damaging worked surfaces and diagnostic details, and to minimise visual impact. Samples were processed and dated at the Leibniz-Labor, Christian-Albrechts University, Kiel, Germany. Before collagen extraction, the burial 74 sample, which had been conserved with wax, was extracted three times each with boiling tetrahydrofurane (THF), chloroform, petroleum-ether, acetone, and methanol and then rinsed with demineralized water. All samples were then demineralized in $\mathrm{HCl}$ and subsequently treated with $\mathrm{NaOH}$ at room temperature to remove mobile humic acids, and re-acidified. The resulting collagen extract was dissolved at $85^{\circ} \mathrm{C}$ and insoluble particles were removed by filtration through a $0.45 \mu \mathrm{m}$ pore silver filter. Freeze-dried collagen was combusted to $\mathrm{CO}_{2}$ in a closed quartz tube and reduced to graphite, and dated following Nadeau et al. (1998). For quality control, bone samples of known ${ }^{14} \mathrm{C}$ age were processed and measured concurrently, with satisfactory results.

A subsample of the collagen extracted for ${ }^{14} \mathrm{C}$ dating was sent to the Aarhus AMS Centre, Aarhus University, Denmark, for duplicate EA-IRMS measurement (elemental analysis-isotope ratio mass spectrometry), using a continuous-flow IsoPrime IRMS coupled to an Elementar PyroCube elemental analyser. All collagen extracts (including those published previously) have acceptable atomic C/N ratios (DeNiro 1985).

AMS and EA-IRMS results are shown in Table II. The human bone sample from burial 100 appears older than the horse tooth pendant found in close association with the same individual, providing the first direct evidence of a dietary reservoir effect. Previous researchers at Zvejnieki have only dated paired samples of a human bone and another bone from the same grave to assess whether the latter was associated with the burial itself (see Meadows et al. 2016 for detail). When the methods and parameter values used by Meadows et al. (2018) to estimate the carbon contribution of freshwater fish to 


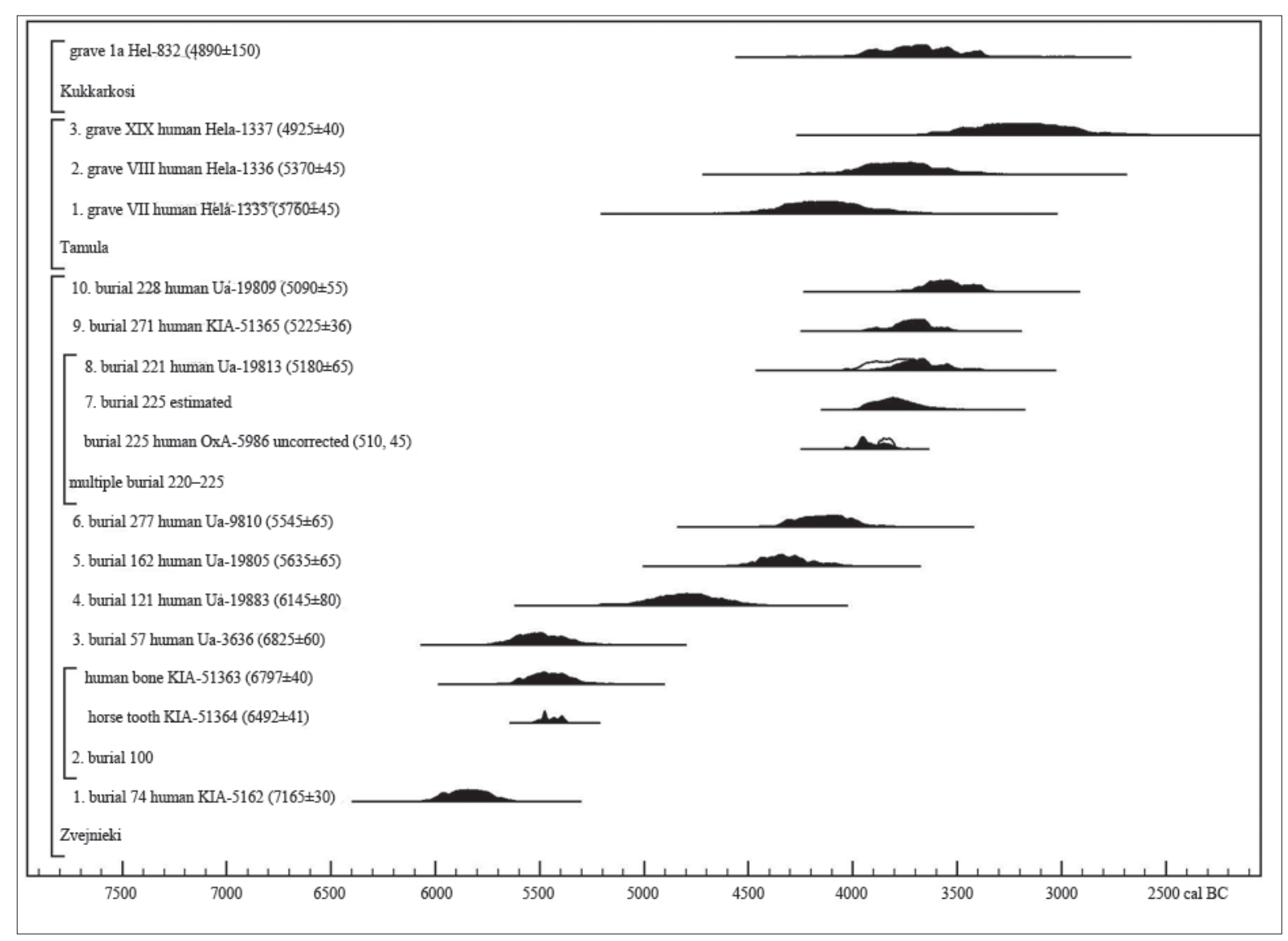

Fig. 2. Radiocarbon dates from burials with artistic representations from Latvia, Estonia and Finland (by John Meadows).

the ${ }^{14} \mathrm{C}$ ages of Zvejnieki human remains are applied to burial 100, a dietary reservoir effect of $292 \pm 92{ }^{14} \mathrm{C}$ years is predicted, in good agreement with the measured offset between the human bone and horse tooth pendant, $305 \pm 58{ }^{14} \mathrm{C}$ years. We have therefore used the same methods and parameter values to estimate the calendar dates of burials for which we only have human bone ${ }^{14} \mathrm{C}$ ages. The FRUITS program (Fernandes et al. 2014) is used to estimate the proportion of fishderived carbon in collagen from each sample, based on stable isotope values, and the Mix_Curves function in OxCal v4.2 (Bronk Ramsey 2009) is then used to estimate the real calendar age of each burial, again assuming that the fish-derived carbon was subject to a reservoir effect of $750 \pm 50{ }^{14} \mathrm{C}$ years (Table II; Fig. 2).

\section{Mesolithic and Early Neolithic} burials on the north-western slope of the gravel ridge

The burials with anthropomorphic and zoomorphic representations in the oldest group of burials include nos. 74, 57, 100 and 121. All burials in this group are single burials, intensively ochre-strewn and richly adorned with tooth pendant jewellery, some with stone settings at the top of the grave. All of them are located on the north-western slope of the gravel ridge (Fig. 1).

Burial 74 (Fig. 3). This is the burial of an adult female in extended supine position with the head to southwest. The lower part of the burial had been destroyed by a later pit. An intensive ochre layer surrounded the skeleton. Forty tooth pendants were found by the right forearm, from the elbow downwards, and three were located a little higher in the same area. They belong to wild boar, elk and deer, along with one tooth of grey seal (Halichoerus grypus). A bird sculpture made from wild boar tusk had been laid on top of the head. This could be an image of a waterbird with the head broken off. The figurine is $4 \mathrm{~cm}$ long, $1.2 \mathrm{~cm}$ wide and $0.4 \mathrm{~cm}$ thick. The surface consists of the shiny part of the tusk, and traces of working - cutting and grooving - were visible on the underside. As these traces are very pronounced and "fresh", it is possible that the figurine was made specially to serve as a grave good (Fig. 17: 1).

The burial is dated to the earlier sixth millennium cal BC (Fig. 2, KIA-51362).

Burial 100 (Fig. 4). This was the burial of an infant of indeterminate sex (infans II), laid in extended supine position with the head to north-east. An intensive ochre layer surrounded the skeleton. One large, flat stone and
I

STONE AGE IN NORTHERN EUROPE: CHANGES IN LANDSCAPE, TECHNOLOGIES AND BELIEFS 
Table II. Radiocarbon dated burials with artistic representations from Latvia, Estonia and Finland. Calibration of radiocarbon dates for individual burials in accordance with Table I.

Radiocarbon ages were calibrated using OxCal v4 (Bronk Ramsey 2009) and the IntCal13 calibration data (Reimer et al. 2013). With the exception of Zvejnieki burial 225, human dates have been corrected for estimated dietary reservoir effects, following Törv 2016, Table 20 (Tamula) and the method and parameter values used by Meadows et al. 2018 (Zvejnieki). The date of Zvejnieki burial 225 cannot be corrected by this method, as stable isotope results are not available, but simple calibration of OxA-5986 provides a maximum age, and the corrected date of the overlying burial 221 provides a minimum age; the date of burial 225 can therefore be estimated. Based on excavation evidence, however, burials 220-225 were probably contemporaneous (according to John Meadows).

\begin{tabular}{|c|c|c|c|c|c|c|c|c|c|c|c|c|c|}
\hline No & $\begin{array}{c}\text { Gra- } \\
\text { ve }\end{array}$ & sex, age & $\begin{array}{l}\text { element } \\
\text { sampled, } \\
\text { collagen } \\
\text { yield }\end{array}$ & $\begin{array}{c}\text { labora- } \\
\text { tory code }\end{array}$ & $\% \mathrm{C}$ & $\% \mathrm{~N}$ & $\begin{array}{l}\mathrm{C}: \mathrm{N} \\
\text { ato- } \\
\text { mic }\end{array}$ & $\begin{array}{c}\delta 13 C \\
(\%)\end{array}$ & $\begin{array}{c}\delta 15 N \\
(\% 0)\end{array}$ & $\begin{array}{c}14 \mathrm{C} \\
\operatorname{age}(\mathrm{BP})\end{array}$ & $\begin{array}{c}\text { original } \\
\text { publication }\end{array}$ & 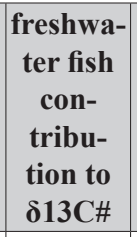 & $\begin{array}{c}\text { modelled } \\
\text { date (cal } \\
\text { BC, 95\% } \\
\text { proba- } \\
\text { bility) }\end{array}$ \\
\hline 1 & 74 & $\begin{array}{l}\text { human, F, } \\
\text { adult }\end{array}$ & $\begin{array}{l}\text { mandible, } \\
18.3 \% \text { collagen }\end{array}$ & KIA-51362 & 43.0 & 15.5 & 3.2 & -22.6 & 10.6 & $7165 \pm 30$ & this paper & $31 \pm 13 \%$ & $6050-5650^{*}$ \\
\hline \multirow[t]{2}{*}{2} & 100 & $\begin{array}{l}\text { human, } \\
\text { infant II }\end{array}$ & $\begin{array}{l}\text { bone, } 14.3 \% \\
\text { collagen }\end{array}$ & KIA-51363 & 43.5 & 16.2 & 3.1 & -22.8 & 11.8 & $6797 \pm 40$ & this paper & $39 \pm 12 \%$ & $5650-5250^{*}$ \\
\hline & & $\begin{array}{l}\text { wild horse } \\
\text { (Equus } \\
\text { ferus) }\end{array}$ & $\begin{array}{l}\text { tooth root, } \\
2.9 \% \text { collagen }\end{array}$ & KIA-51364 & 36.6 & 13.3 & 3.2 & -25.3 & 5.4 & $6492 \pm 41$ & $\begin{array}{l}\text { 14C: this paper; } \\
\text { EA-IRMS: } \\
\text { Eriksson (2006) }\end{array}$ & - & $5530-5360 \S$ \\
\hline 3 & 57 & $\begin{array}{l}\text { human, F, } \\
\text { adult }\end{array}$ & $\begin{array}{l}\text { 14C: } \text { not } \\
\text { recorded; EA- } \\
\text { IRMS: skull, } \\
3.3 \% \text { collagen }\end{array}$ & Ua-3636 & 44.7 & 15.7 & 3.3 & -22.8 & 11.8 & $6825 \pm 60$ & $\begin{array}{l}\text { 14C: Zagorska } \\
\text { (1997); } \\
\text { EA-IRMS: } \\
\text { Meadows et al. } \\
(2016)\end{array}$ & $36 \pm 15 \%$ & $5750-5250 *$ \\
\hline 4 & 121 & $\begin{array}{l}\text { human, F, } \\
\text { adult }\end{array}$ & $\begin{array}{l}\text { skull, } 6.9 \% \\
\text { collagen }\end{array}$ & Ua-19883 & 44.4 & 15.6 & 3.3 & -23.1 & 10.9 & $6145 \pm 80$ & $\begin{array}{l}\text { 14C: Eriksson et } \\
\text { al. (2003); EA- } \\
\text { IRMS: Eriksson } \\
(2006)\end{array}$ & $34 \pm 15 \%$ & $5250-4450^{*}$ \\
\hline 5 & 162 & $\begin{array}{l}\text { human, } \mathrm{M} \text {, } \\
\text { adult }\end{array}$ & $\begin{array}{l}\text { fibula, } 0.6 \% \\
\text { collagen }\end{array}$ & Ua-19805 & 36.2 & 13.2 & 3.2 & -22.3 & 10.1 & $5635 \pm 65$ & $\begin{array}{l}\text { Eriksson et al. } \\
(2003)\end{array}$ & $22 \pm 13 \%$ & $4550-4050^{*}$ \\
\hline 6 & 277 & $\begin{array}{l}\text { human, } \mathrm{M} \text {, } \\
\text { adult }\end{array}$ & $\begin{array}{l}\text { femur, 9.6\% } \\
\text { collagen }\end{array}$ & Ua-19810 & 42.3 & 15.8 & 3.1 & -22.6 & 11.7 & $5545 \pm 65$ & $\begin{array}{l}\text { Eriksson et al. } \\
(2003)\end{array}$ & $35 \pm 15 \%$ & $4400-3800 *$ \\
\hline 7 & 225 & $\begin{array}{l}\text { human, } \mathrm{M}, \\
\text { mature }\end{array}$ & $\begin{array}{l}\text { humerus, } 2.9 \% \\
\text { collagen }\end{array}$ & OxA-5986 & & & & -21.2 & & $5110 \pm 45$ & \begin{tabular}{|l|} 
Zagorska and \\
Larsson (1994)
\end{tabular} & $?$ & $4000-3550 \dagger$ \\
\hline 8 & 221 & $\begin{array}{l}\text { human, F, } \\
\text { mature }\end{array}$ & \begin{tabular}{|l|}
$\begin{array}{l}\text { skull, } 3.7 \% \\
\text { collagen }\end{array}$ \\
\end{tabular} & Ua-19813 & 39.9 & 13.4 & 3.5 & -21.3 & 12.7 & $5180 \pm 65$ & $\begin{array}{l}\text { Eriksson et al. } \\
(2003)\end{array}$ & $31 \pm 15 \%$ & $3900-3350^{*}$ \\
\hline 9 & 271 & $\begin{array}{l}\text { human, } \\
\text { infant }\end{array}$ & $\begin{array}{l}\text { skull, } 7.5 \% \\
\text { collagen }\end{array}$ & KIA-51365 & 43.3 & 15.5 & 3.3 & -23.3 & 13.0 & $5225 \pm 36$ & this paper & $46 \pm 11 \%$ & $3950-3350 *$ \\
\hline 10 & 228 & $\begin{array}{l}\text { human, } \mathrm{M}, \\
\text { mature }\end{array}$ & $\begin{array}{l}\text { scapula, } 5.3 \% \\
\text { collagen }\end{array}$ & Ua-19809 & 41.9 & 15.6 & 3.1 & -24.0 & 12.1 & $5090 \pm 55$ & $\begin{array}{l}\text { Eriksson et al. } \\
(2003)\end{array}$ & $47 \pm 12 \%$ & $3800-3300 *$ \\
\hline 1 & VII & human & $\begin{array}{l}\text { 14C: mandible; } \\
\text { EA-IRMS: } \\
\text { M1, } 2.0 \% \text { col- } \\
\text { lagen }\end{array}$ & Hela-1335 & 39.8 & 13.7 & 3.4 & -24.0 & 14.0 & $5760 \pm 45$ & $\begin{array}{l}\text { 14C: Kriiska } \\
\text { et al. (2007); } \\
\text { EA-IRMS: Tõrv } \\
(2016)\end{array}$ & $50 \pm 8 \%$ & $4500-3700$ \\
\hline 2 & VIII & human & $\begin{array}{l}\text { 14C: left } \\
\text { femur;EA- } \\
\text { IRMS: M1, } \\
\text { M2, M3, 1.0- } \\
3.0 \% \text { collagen }\end{array}$ & Hela-1336 & $\begin{array}{l}37.3 \\
39.3 \\
39.2\end{array}$ & $\begin{array}{l}13.2 \\
14.3 \\
14.2\end{array}$ & $\begin{array}{l}3.3 \\
3.2 \\
3.2\end{array}$ & \begin{tabular}{|l|}
-23.1 \\
-23.9 \\
-23.8
\end{tabular} & $\begin{array}{l}13.5 \\
12.7 \\
12.2\end{array}$ & $5370 \pm 45$ & $\begin{array}{l}\text { 14C: Kriiska } \\
\text { et al. (2007); } \\
\text { EA-IRMS: Tõrv } \\
(2016)\end{array}$ & $44 \pm 10 \%$ & $4150-3350$ \\
\hline 3 & XIX & human & femur & Hela-1337 & & & & -25.0 & & $4925 \pm 40$ & $\begin{array}{l}\text { 14C: Kriiska et } \\
\text { al. (2007) }\end{array}$ & $51 \pm 10 \%$ & $3650-2700$ \\
\hline 1 & $1 \mathrm{a}$ & charcoal & & Hel-832 & & & & & & $4890 \pm 150$ & Torvinen (1978) & & $4040-3350 \S$ \\
\hline
\end{tabular}

\# estimated using FRUITS (Fernandes et al. 2014) and parameter values given by Meadows et al. (2018, no marine food group), or (Tamula) by Tõrv (2016, Figure 30)

$\S$ calibration with IntCal13 (Reimer et al. 2013); range rounded outwards to 10 years

* reservoir-effect-corrected date: calibration with IntCal13, Delta_R of $750 \pm 50$ years applied to the estimated freshwater contribution to $\delta 13 \mathrm{C}$; range rounded outwards to 50 years

I| reservoir-effect-corrected date: calibration with IntCal13, Delta_R of $1000 \pm 350$ years applied to the estimated freshwater contribution to $\delta 13 \mathrm{C}$; range rounded outwards to 50 years

$104 \uparrow$ modelled estimate of a date earlier than the reservoir-effect-corrected date of the overlying burial, 221, and not earlier than the calibration of OxA-5986; range rounded outwards to 50 years 


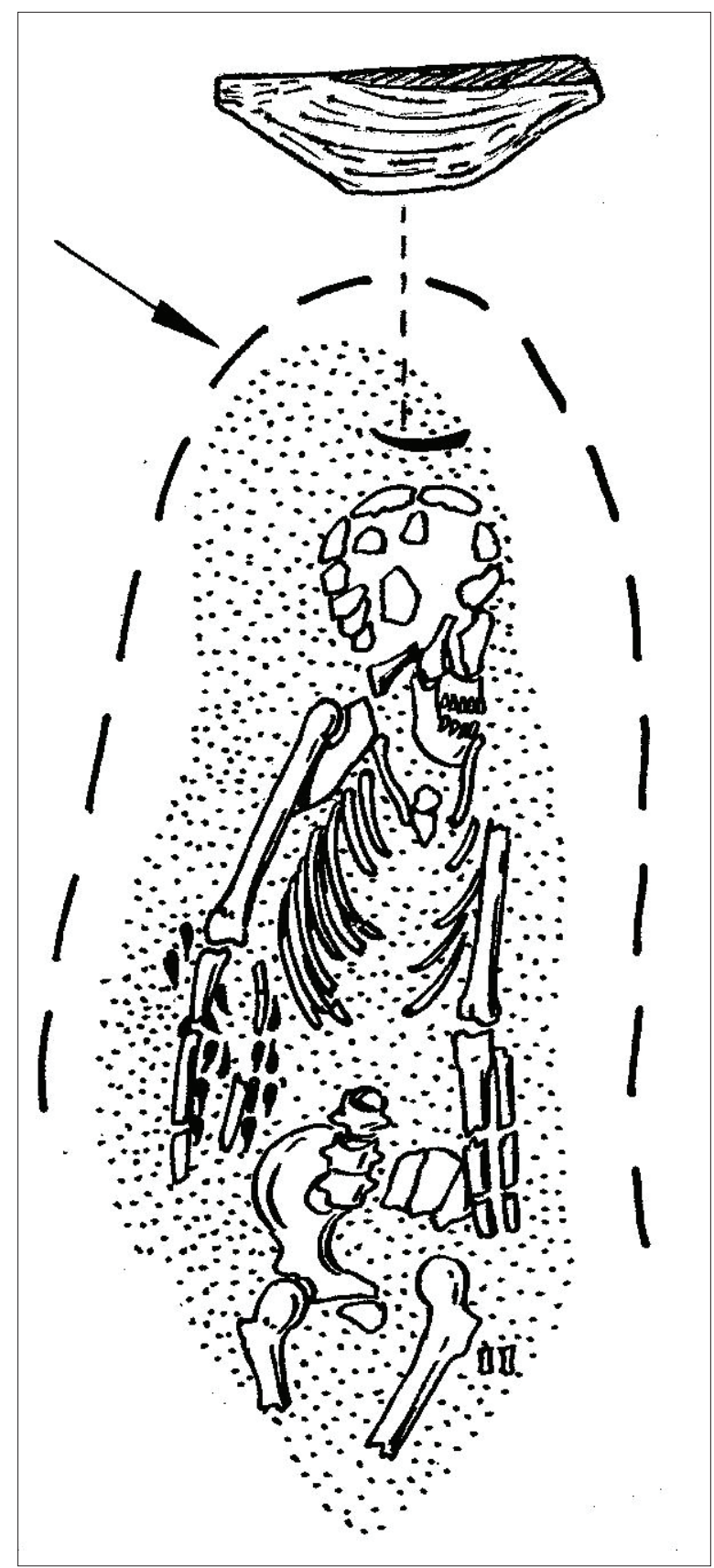

Fig. 3. Burial 74, Zvejnieki.

two smaller stones had been placed at the north-eastern end of the grave, covering the skull. Densely packed stones covered the south-western end of the grave, but no stones were observed over the central part of the grave. The fill of the grave was dark earth. Elaborate ornaments, consisting of 72 tooth pendants in total, were found in different locations: there were pendants on the left shoulder, two rows of pendants crossing the waist, and a concentration of pendants covering the femora (wild boar, elk, red deer, aurochs and wild horse). A zoomorphic figurine was recovered close to the left elbow, between the bones of the skeleton, together with a row of tooth pendants consisting of elk, wild boar and some horse teeth. The figurine is $7.3 \mathrm{~cm}$ long, made of a bird mandible (Zagorskis 2004, 68). The bone had been damaged at the wider end. There is a perforation in the narrower end, with an incision at the tip. One face of the figurine is covered in crosshatched incisions, forming a row of rhomboid ornamentation (Fig. 17: 3). The figurine is very schematic and could represent the head of a bird or animal. Considering the position of the figurine, it may have been fastened to the belt. The burial is dated to the mid-sixth millennium (Fig. 2, KIA-51364).

Burial 57 (Fig. 5). This is a well-known grave, containing the burial of an adult female. The whole grave was covered by stones, in addition to which there were stones in the fill of the grave. The burial was in extended supine position with the head to north-west. An intensive ochre layer surrounded the skeleton and the sides of the pit. The grave inventory was very rich, including a bone spearhead, a flat stone axe as well as pendants, 42 altogether, made from elk, red deer and aurochs teeth, which were found on and beside the skeleton, and as decorations on other grave goods. The main find in this grave was a bone dagger with an elk head representation forming the handle. It is 24 $\mathrm{cm}$ long, the handle being $7 \mathrm{~cm}$ long. The handle was somewhat damaged, with no preserved detail, and so it now appears very schematic, with a slightly drooping muzzle (Fig. 16: 5). This elk sculpture was found at the knees of the interred woman, across the left leg, with the handle pointing downwards. Daggers with elk head handles are very well known in Stone Age art and could be real daggers or elements of compound artefacts - staffs or effigies.

The burial is also dated to the mid-sixth millennium cal. BC (Fig. 2, Ua-3636).

Burial 121 (Fig. 6). The grave contained the burial of an adult female in extended supine position with the head to the south, and with an intensive ochre layer around the skeleton. The grave was shallow, 10-20 $\mathrm{cm}$ from the ground surface, and the leg bones downwards from the knees had been destroyed, but most of the skeleton was in anatomical order. Animal tooth pendants surrounded the interred individual, being found on the chest and shoulders, along the arms and by the pelvis and legs. These tooth pendants belong to elk, wild boar, aurochs as well as dog, otter and fox. Bones of beaver and two bird bones (Mergus?) were also found. A perforated seal phalange was found at the right elbow. A smoothed oval pebble more than $5 \mathrm{~cm}$ long and a figural stone object were documented over the right side of the pelvis (Fig. 17: 7, 8). This indeterminate object is made of a slab of gneiss, with a wider middle section and with some traces of working. It is

\section{I}

STONE AGE IN NORTHERN EUROPE: CHANGES IN LANDSCAPE, TECHNOLOGIES AND BELIEFS 


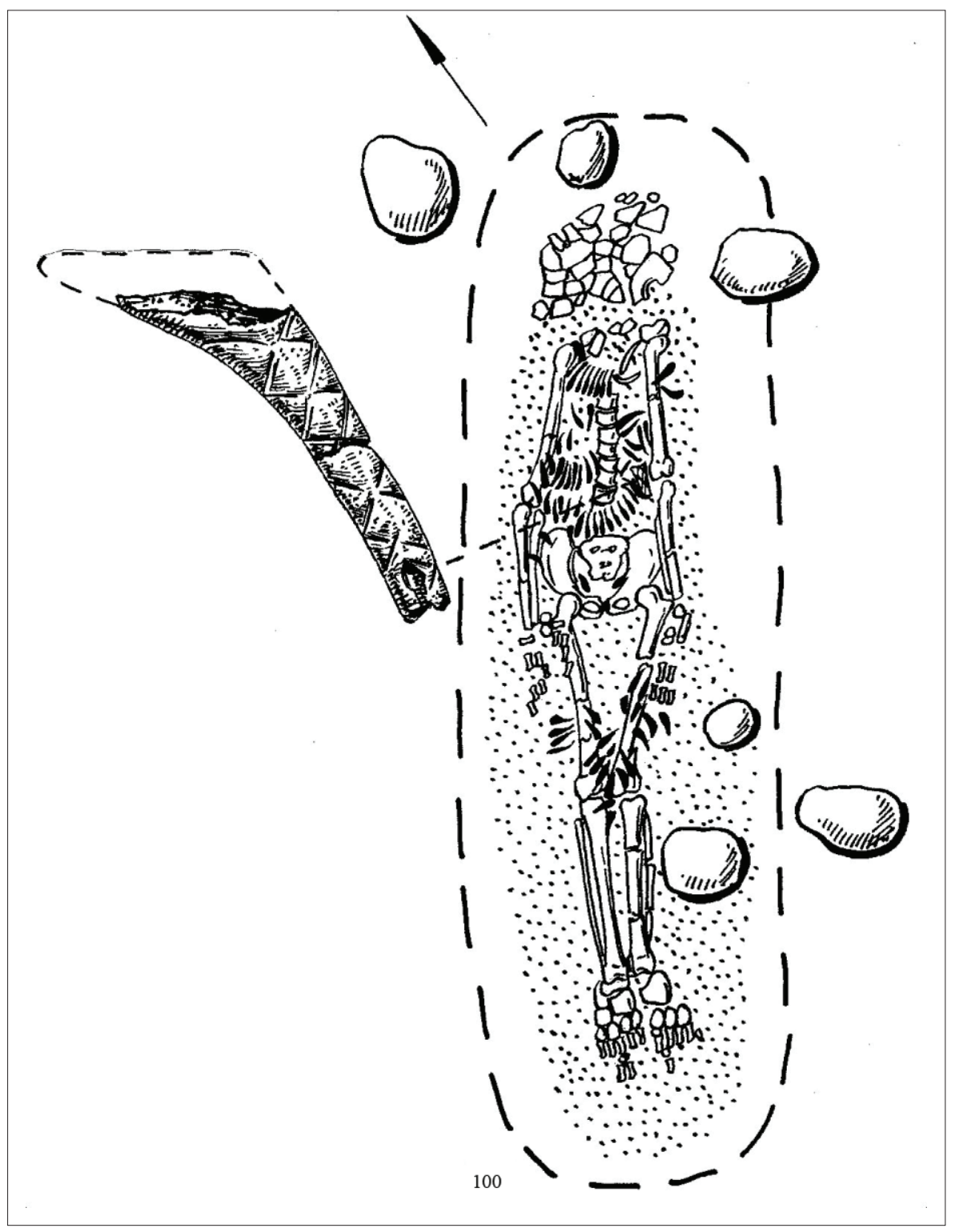

Fig. 4. Burial 100, Zvejnieki.

$4.3 \mathrm{~cm}$ long, $2.6 \mathrm{~cm}$ wide and $1.2 \mathrm{~cm}$ thick. Zagorskis considered it a zoomorphic figurine, but also it could be an anthropomorphic depiction. More detailed characterisation of this find would require careful use-wear analysis.

The burial is dated to the late sixth or earlier fifth millennium cal. BC (Fig. 2, Ua-19883).

\section{Late Early Neolithic burials}

in the middle part of burial ground, on the southern slope

of the gravel ridge

Only one burial of this group has been dated, no. 162 , but burial 172, situated between two groupings of graves, may also be included in the group on typological grounds (Fig. 1). These were single graves, distinguished by a fill of black earth, and were partially strewn with ochre. Both of the mentioned burials had been partly destroyed.

Burial 162 (Fig. 7). This is the burial of an adult male, laid in extended supine position with the head to the east and with black earth filling the grave. Only the head area was strewn with ochre. The upper part of the skeleton had been disturbed: the right arm, ribs and vertebra were damaged. Six tooth pendants, from elk and aurochs, were found by the knees. A small bone figurine was discovered under the pelvis at the right side of the interred person. It is small, only $4.6 \mathrm{~cm}$ long, in the form of an irregular triangle, highly polished on all sides. The longest part of the "triangle" has been flattened on both sides and perhaps served as a handle for attachment to a shaft. The figurine is so schematic that it is difficult to say whether it represents 

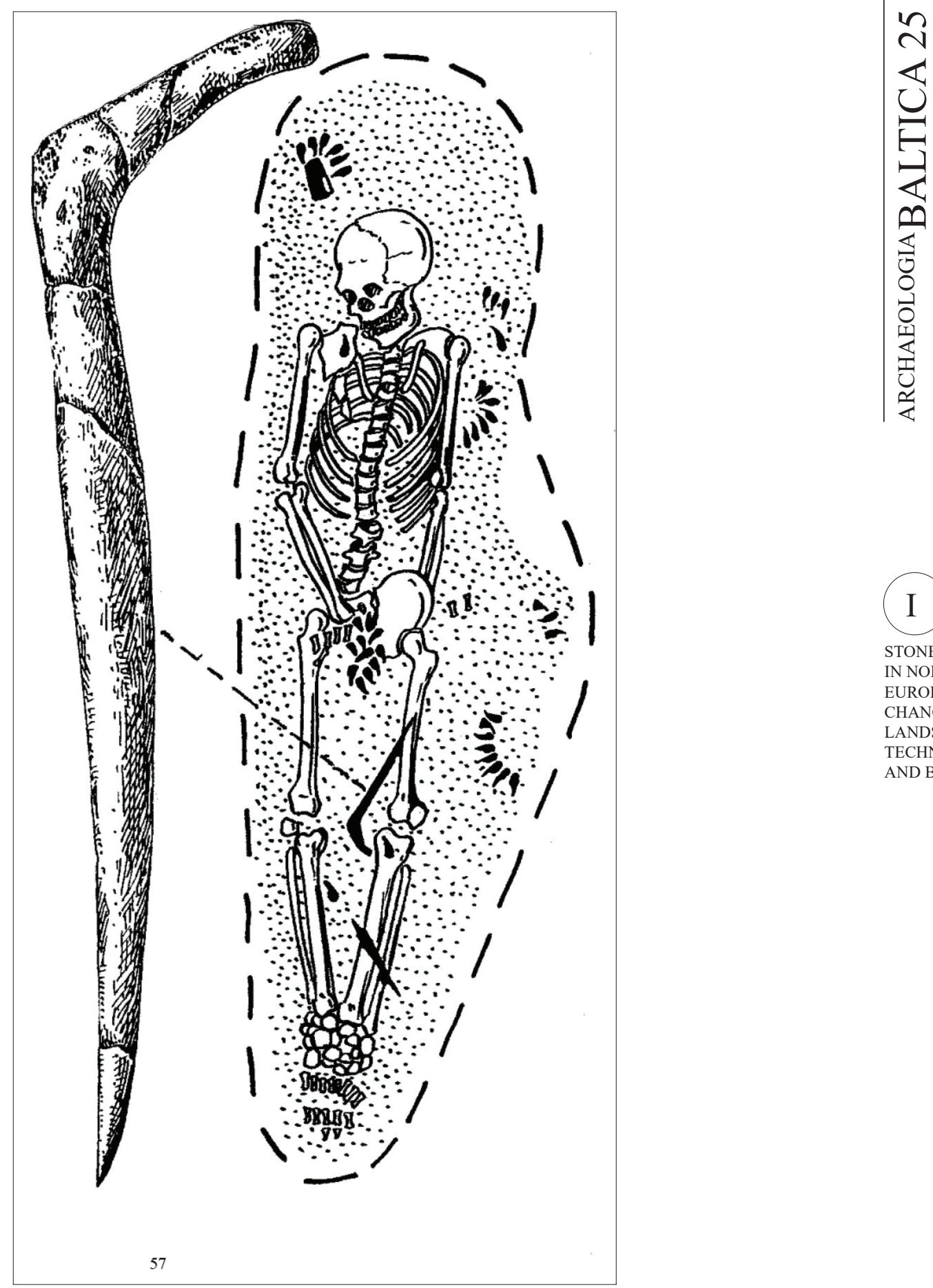

I

STONE AGE IN NORTHERN EUROPE: CHANGES IN LANDSCAPE, TECHNOLOGIES AND BELIEFS

Fig. 5. Burial 57, Zvejnieki.

the head of an animal or a bird (Fig. 17: 4). Zagorskis considered it the head of a waterbird, and this idea is supported by finds of heads of waterbirds carved from small bone pieces, which occur on settlements and burials of the Russian north (Studzitskaja 1994, Fig. 4). The burial is dated to the later fifth millennium cal. BC (Fig. 2, Ua-19805).

Burial 172 (Fig. 8). This burial was totally disturbed: the disarticulated bones of an infant were found in an area extending south-west to north-east. The bones were surrounded by black earth with occasional patches of ochre. As the bones were not collected in the course of excavation, radiocarbon dating of the burial is not possible. At the very end of the black contour of the grave, a female human figurine was discovered, made from an antler plaque. Thirteen centimetres in length, with a thickness of $0.7 \mathrm{~cm}$, it has survived in full; only small pieces have broken off from both sides of the head. The head is joined to the body by a fairly thick neck. The figurine has been worked from the up- 


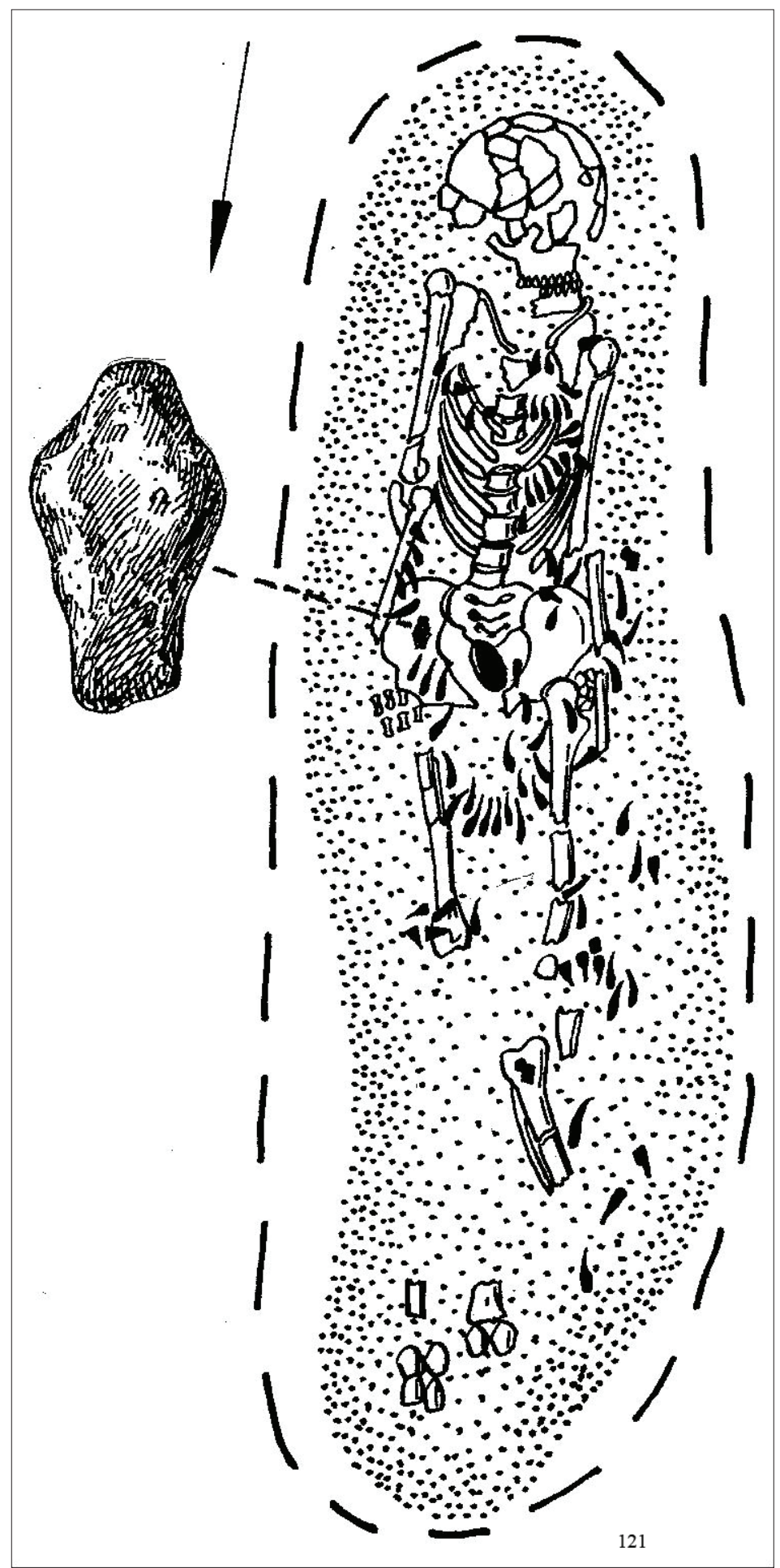

Fig. 6. Burial 121, Zvejnieki.

per side. Incised lines indicate bent arms and legs, the feet turned outwards. The outer margin of the whole sculpture as well as the lines distinguishing the arms and legs are decorated with carved triangular notches. Two perforated holes in the upper part of figurine may indicate the breasts, and an oval perforation represents the vulva. The perforations could have been used for fastening the object to the dress (Fig. 16: 4). The sculpture is polished and shiny, but some scratches on its
A human figurine very similar in form and style has been found by the Old Siass Canal in the southern part of the Lake Ladoga region of north-western Russia; the only differences are in the form of the head and the ornamentation method. These finds are considered to be Early Neolithic, as Narva Ware ceramics dominated at this site (Timofeev 1993, 21), but more reliable data are absent. 


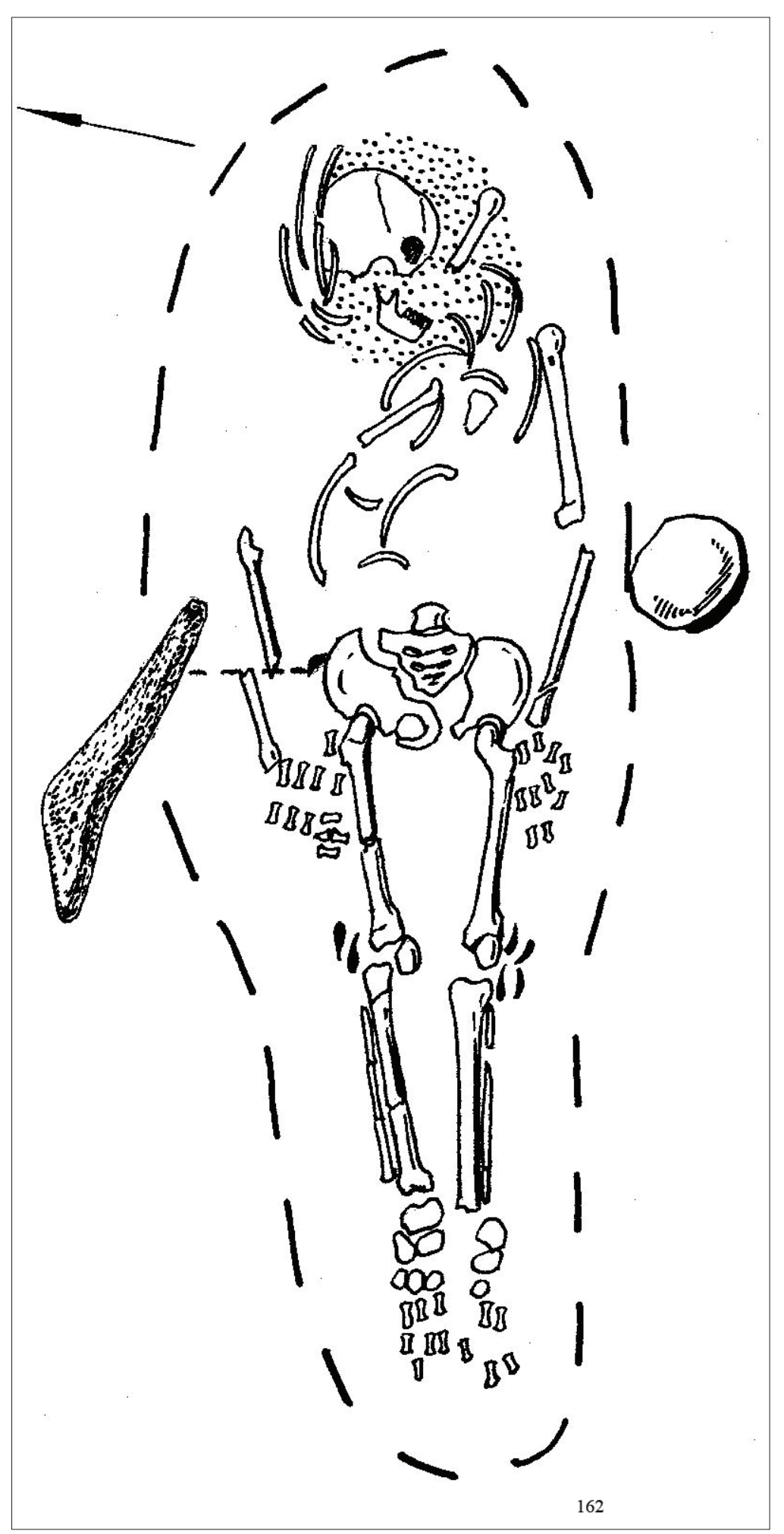

STONE AGE IN NORTHERN EUROPE: CHANGES IN LANDSCAPE, TECHNOLOGIES AND BELIEFS

Fig. 7. Burial 162, Zvejnieki

Middle Neolithic burials around the Zvejnieki farmstead

The burials around the Zvejnieki farmstead with anthropomorphic and zoomorphic representations are now all dated, and all are Middle Neolithic. Two subgroups of burials may be distinguished: 1) the first subgroup includes two collective burials, one consisting of five, the other of seven individuals. The collective burials were arranged in pits with dark soil at the bottom, covered by an intensive layer of ochre, strewn over the burials. Adults, adolescents and children were buried together, commonly in opposed orientation. Some individuals in the collective graves were very richly adorned with amber jewellery, flint, bone, antler and stone grave goods, as well as artistic representations. 


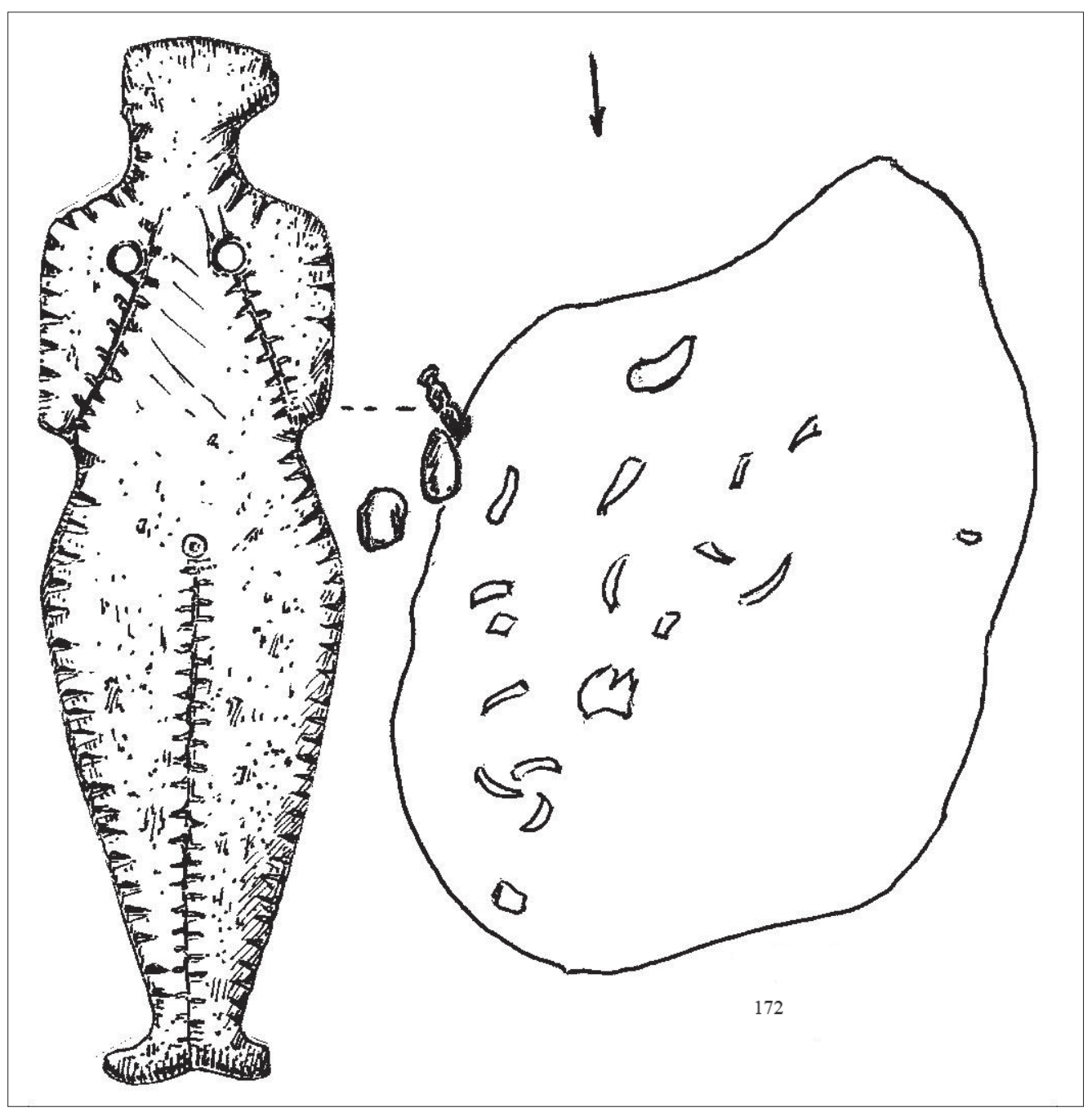

Fig. 8. Burial 172, Zvejnieki.

2) The second subgroup consists of two single burials with a fill of black earth in the grave, continuing the previously described Early Neolithic burial traditions.

The collective burial 274-278 (Fig. 9) contained five individuals: a young female (juvenis, no. 274) with fragmentarily preserved bones, followed in a second layer by four individuals, two of them with heads to the west, the other two oriented to the east. These were: adult male no. 275 , mature male no. 276 , adult male no. 277 and infant no. 278 (infans II, recently indicated as male, information from Gunita Zarina). Very rare burial traditions were observed in this collective burial: the heads of male burials 275 and 277 were covered with blue-grey clay, and the eye sockets of no. 275 contained two amber rings (Zagorska 1997). It was difficult to understand the association of the other grave goods with the burials, as the interred individuals had been laid very close together. The focus of interest here is in the arrangement of male burial 277, which is dated to the late fifth or early fourth millennium (Fig. 2, Ua-19810). Study of the documentation indicates that the objects associated with this individual include some amber objects (a ring and a bead), some tooth pendants (four marten teeth and one pig tooth - Sus $s p$.) on the chest and pelvis. The amber jewellery in the area of the knees is thought to belong to an adjacent male burial (no. 276). The main grave goods with burial 277 are two copper rings - one inside the right lower leg, the other outside the left femur - and an elk head staff made of antler in the area of the feet (Fig. 16: 6).

The elk head is very realistically depicted. Typical features of the animal head are accentuated: the drooping lower lip, the muzzle and nostrils, and the two small ears. The mouth is marked by a groove, while the eyes are slightly bulging. The head is attached to a fairly long neck. The obliquely cut end of the staff, with a small ridge at the very end, is evidence that the sculpture was attached to a haft. The sculpture is $10 \mathrm{~cm}$ long, the head of the animal being $5 \mathrm{~cm}$ long. Another interpretation, supported by palaeozoologists, is that it may be a horse's head (in view of the long, straight neck). Likewise Zagorskis, in describing his first impression 


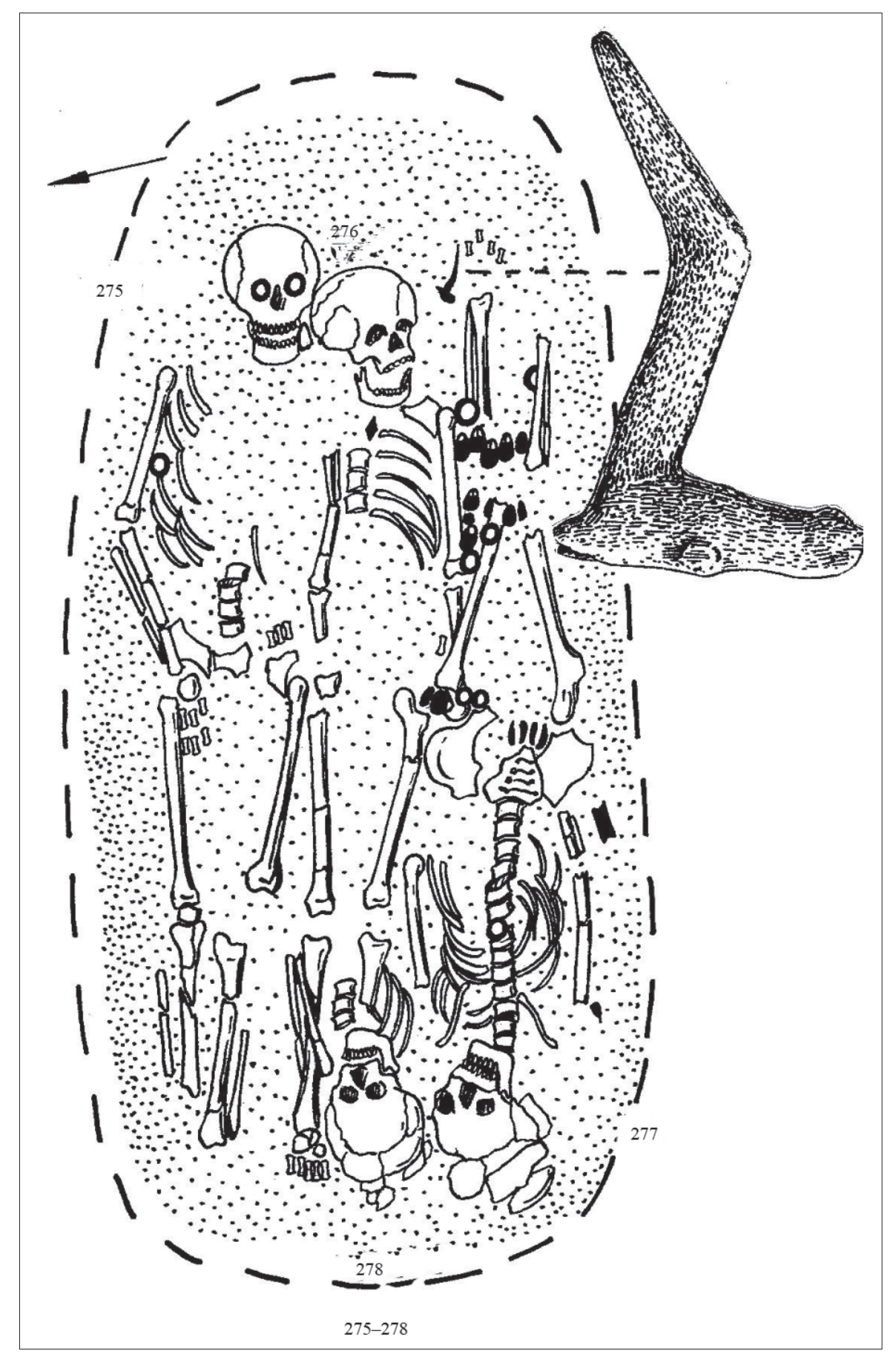

记

I

STONE AGE IN NORTHERN EUROPE: CHANGES IN LANDSCAPE, TECHNOLOGIES AND BELIEFS

Fig. 9. Burials 274-278, Zvejnieki.

of the discovery of this sculpture in his diary, mentions that "a small antler horse was discovered". The antler staff had been laid to the left of the feet of this individual, with the head upwards and the handle downwards.

Collective burial 220-225 (Fig. 10). Seven individuals had been placed in the grave: five oriented to the south-east (220 adult male, 221 adult female, 221a child, 222 adult female and 223 adult individual) and two oriented to north-west (adult individual 225 and a child - 224). One of the children (no. 224) was determined as male, while burial 221 was recorded as a male by Zagorskis (2004), but was recently determined to be female (DNA analyses, Gunita Zarina, pers comm, March 2018).

A male (no. 220) without grave goods was buried in black earth at the top of the grave. All the other individuals were laid in a second layer and were ochre-strewn. This collective burial was very richly adorned with amber jewellery, bone, antler and slate artefacts, and art objects. In some cases it was difficult to determine which individuals the grave goods belonged to. Female burial 221 was covered with 56 amber ornaments from 


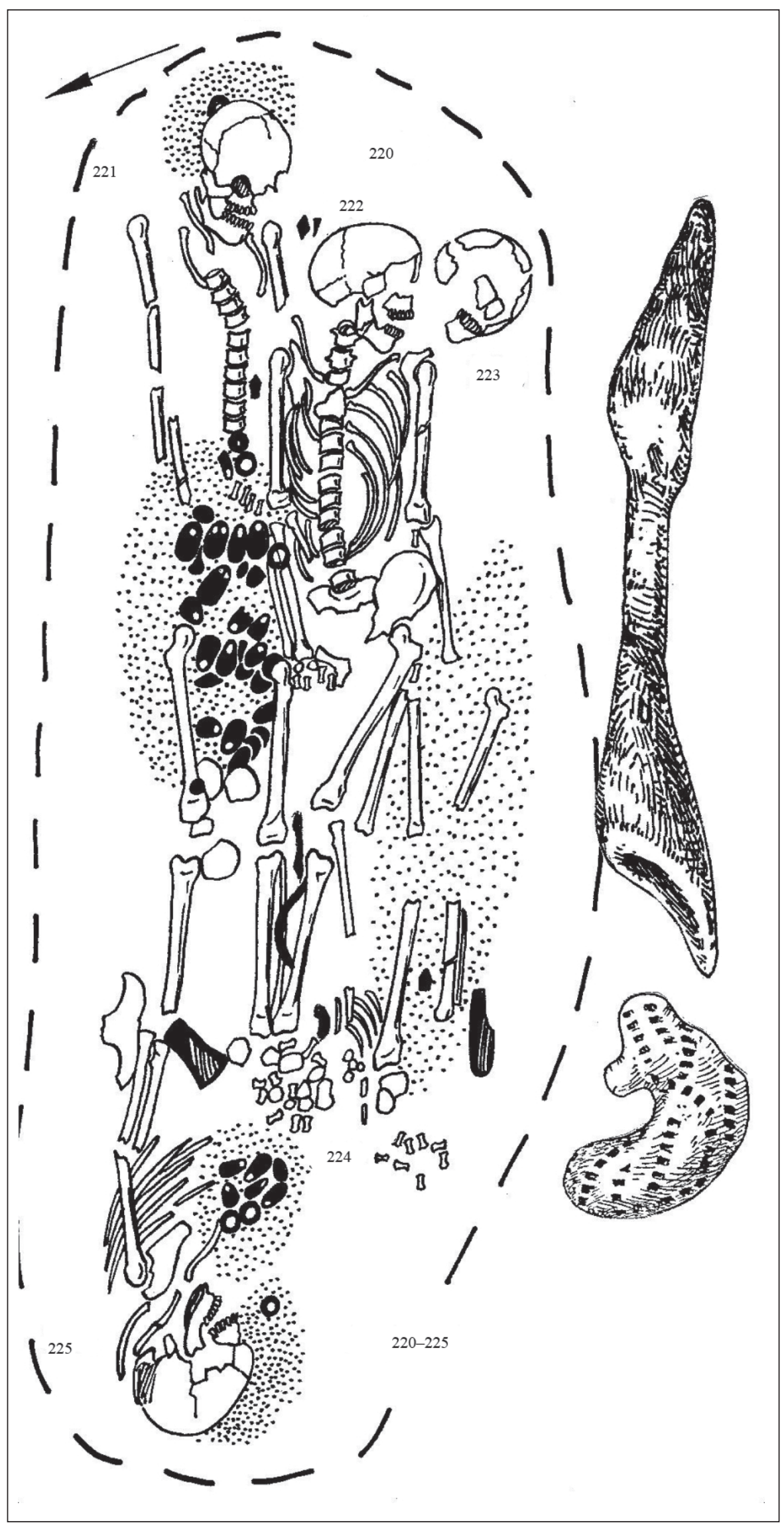

Fig. 10. Burials 220-225, Zvejnieki. 
the middle to the knees, and the woman is thought to have had a child next to her (no. 221a) (Zagorska 2000). In the area of the female's left knee, outside it, an antler figurine was found - a bird with two heads oriented in opposite directions. The figurine had been laid parallel to the leg bones (Fig. 10). A second richly adorned burial was no. 225, with an adult having two small amber rings in the eye sockets, a covering of clay on the face and amber ornaments on the chest. A small child (no. 224) had been laid close to the right hand of this individual in a very intensive layer of ochre, only the head bones and small ribs being preserved. Two small amber rings were found in the area of the child's head, and a small bent clay figurine - an idol - was discovered between the ribs.

The very schematic representation of a waterbird has been carved from a piece of elk antler rod, with the bird's heads facing in opposite directions (Fig.17: 5). The figurine measures $13.4 \mathrm{~cm}$. At one end of the rod there seems to be the head of a duck with a thickened middle part, steeply sloping down to the beak. The other head is narrower and more slender, possibly that of a goose or swan. The motif of two-headed birds is very well known from the Stone Age of northern Russia (Zhulnikov, Kashina 2010).

The small clay figurine is $3.3 \mathrm{~cm}$ high, with a curved section measuring $3.7 \mathrm{~cm}$ and the width of the lower body reaching $2.3 \mathrm{~cm}$. The figurine is oval in crosssection, and the end is rounded. It is made from greybrown clay with an admixture of organic matter. The whole surface of the figurine is covered by comb stamp decoration (Fig. 16: 3). This object is interpreted by Zagorskis as a bear, but in the archaeological literature such figurines are also described as convex-concave or bent idols, being very well known from Stone Age sites in Estonia, Finland and northern Russia (Nunez 1986; Loze 1995; Butrimas 2000). We interpret this find as an embryonic human figurine.

Burials 221 and 225 were both dated directly (Ua19813 and OxA-5986 respectively), but dietary stable isotopes were only measured in burial 221. Burials 224 and 225 are stratigraphically earlier than burial 221 and cannot be older than the simple calibration of OxA-5986, or later than the diet-corrected date of burial 221. The entire grave assemblage is attributed to the early-mid fourth millennium cal BC (Fig. 2).

The other subgroup of Neolithic burials includes two single graves provided with artistic representations, nos. 271 and 228, the latter being very rich in bone and antler sculptures.

Burials 271 and 271a (Fig. 11). This grave contained an adult male (no. 270) with a small child (no. 271a).
The legs of the adult had been disturbed below the knees with the digging of another grave - no. 266. The body had been laid in black earth in extended supine position, with the head to the south-east. There was an ochre-strewn area around the upper part of the right leg. In this area two small leg bones of the child were found, under the right femur of the adult. A carved antler figurine was found outside the right femur. It represents an animal head and had been fastened to some kind of shaft, but the part with the attachment had broken off. The figurine was $6.7 \mathrm{~cm}$ long. The head of the animal is elongated, with small, flattened ears, the eyes marked by small protuberances, the top of the muzzle broadened, and the mouth indicated by a deep incision; the neck is short. Judging from the realistic depiction of the figurine, it could be an animal well known in the area. Zagorskis considered it to be a sculpture of a marten, but it could be some other animal, perhaps an aquatic animal - a beaver or otter. The latter interpretation seems more credible (Fig. 16: 7). The figurine had been laid with the animal's head upwards and the broken shaft downwards. It is apparent that this sculpture was provided for a child (burial 271a). Judging from the smoothed, shiny surface and broken shaft, this sculpted staff had a long life history. Burial 271 is also dated to the early-mid fourth millennium cal. BC (Fig. 2, KIA-51365).

Burial 228 (Fig. 12). In terms of artistic representations, this burial of a mature male is the richest in the whole burial ground. The body was laid in black earth, in extended supine position with the head to the east. A string of 17 amber buttons and a miniature flint arrowhead were unearthed above the chest. Four bone and antler figurines were found close to the head - under the chin - two of them representing birds, the other two being anthropomorphic sculptures.

Two figurines represent human heads. One is made from a $6 \mathrm{~cm}$ long antler rod of triangular cross-section. The head is $1.8 \mathrm{~cm}$ long. The human face in profile is very schematically rendered, only the lines of the nose and mouth being marked by notches. The cheeks are indicated by two slightly convex surfaces. The neck is long, carved from the lower part of the antler tine. An extension of the rod with a drilled round perforation has been left for suspending the figurine (Fig. 16: 2). The second figurine is made from a dorsal scute of Baltic sturgeon, naturally triangular in cross-section. The object is $4.3 \mathrm{~cm}$ long, the head being $2.3 \mathrm{~cm}$ high. This human head is similar to the first sculpture: it is schematically represented, with two small notches along one edge of the bone marking the nose and mouth. A perforation has been made for suspension in the upper part of the figurine (Fig. 16: 1).

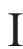

STONE AGE IN NORTHERN EUROPE: CHANGES IN LANDSCAPE, TECHNOLOGIES AND BELIEFS 


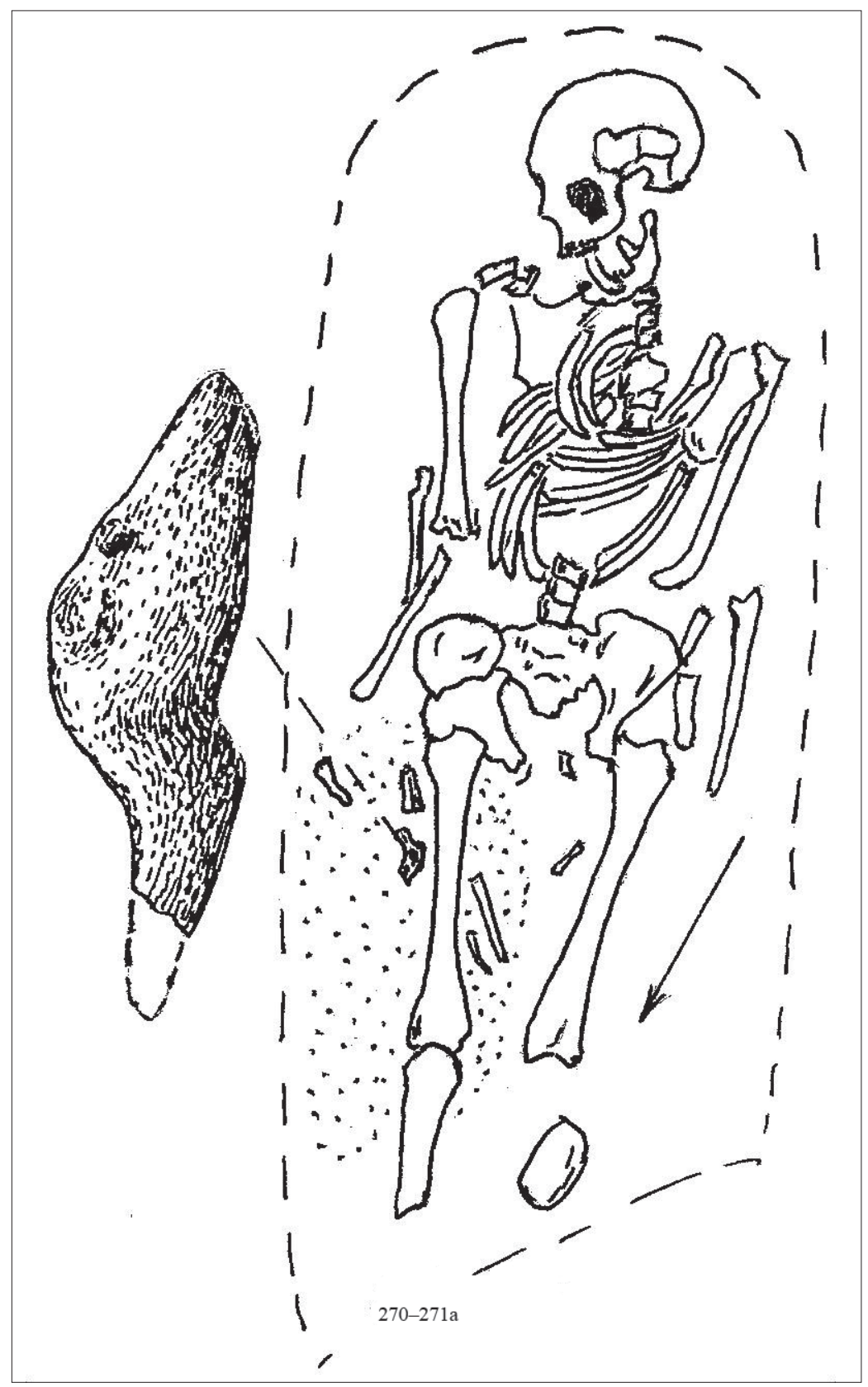

Fig. 11. Burials 271 and 271 a, Zvejnieki.

Quite unique is a bird figurine made out of a bony plate from the head of the sturgeon (Accipenser sturio). The bird figurine measures $5.5 \mathrm{~cm}$ in length, the plate being $0.6 \mathrm{~cm}$ thick. The bird's head is short, with emphasised wattles over the eyes. The neck is a little longer, and the feathers seem to be ruffled, as indicated by small incisions at both sides. The wings appear to be outspread, with a convexity in the middle of the tail. It seems the bird is depicted from above, in flight or during the mating season (Fig. 17: 6). Such a mode of depicting birds is not characteristic of the East Baltic and was previously unknown. In the view of Kristiina Mannermaa, who examined the figurine, it could represent a black grouse (Tetrao tetrix) (Mannermaa 2008, Fig. 16).
From the same grave there is a miniature waterfowl figurine, made from the bony plate of the head of a sturgeon (Fig. 17: 2). The figurine is very fragile, measuring $2.7 \mathrm{~cm}$ in length, with a thickness of $0.3 \mathrm{~cm}$. The bird has an oval body with a raised head, which has broken off. A drilled perforation has been made in the middle of the figurine. Such bird representations are very well known from Stone Age habitation sites and cemeteries in the East Baltic (Tõrv et al. 2017). All these artistic representations - two anthropomorphic and two birds - were found together in a row under the chin of the burial, and could represent a necklace.

Burial 228 is dated to the mid-fourth millennium cal. BC (Fig. 2, Ua-19809). 


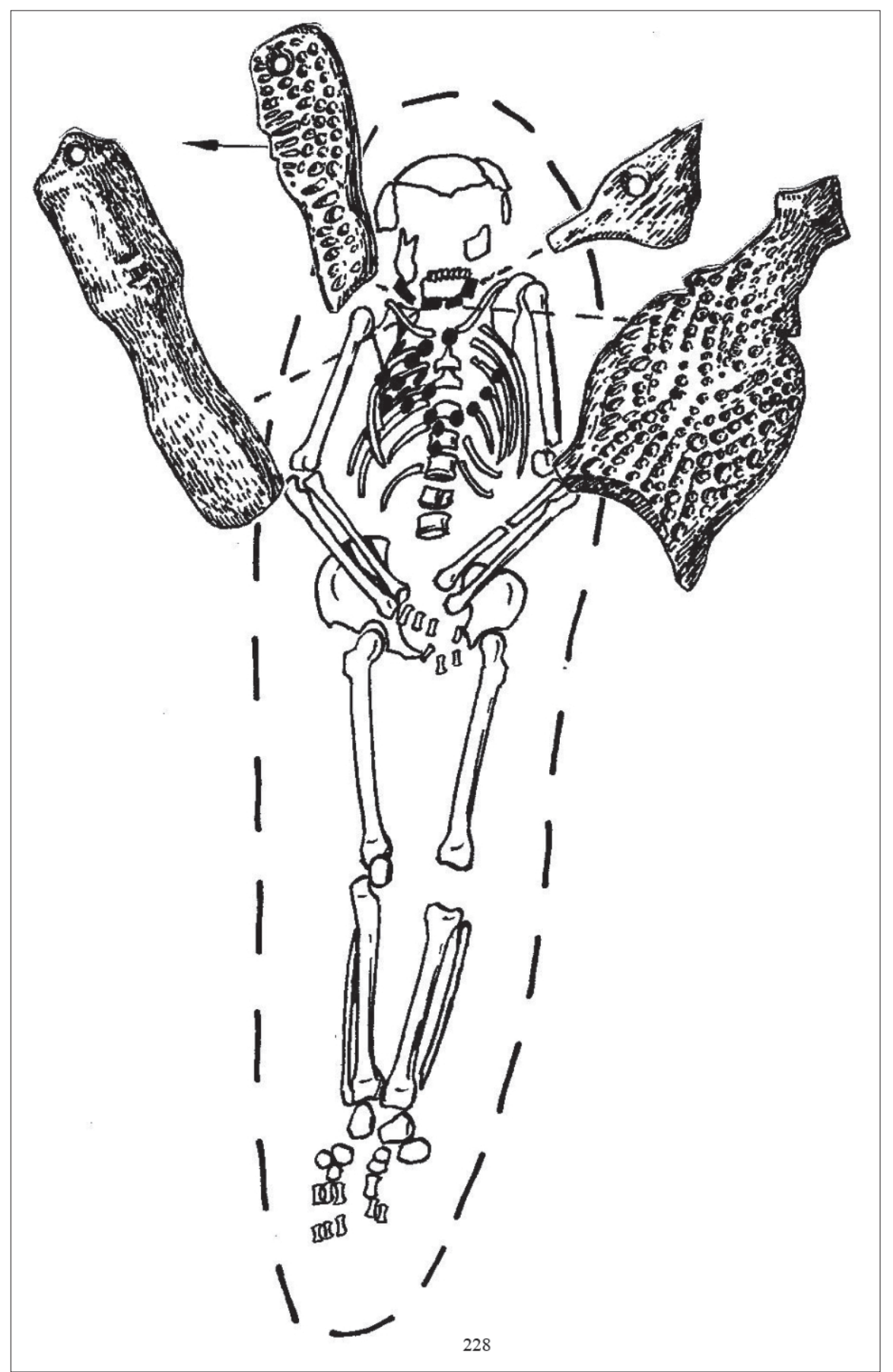

年

I

STONE AGE

IN NORTHERN

EUROPE:

CHANGES IN

LANDSCAPE,

TECHNOLOGIES

AND BELIEFS

Fig. 12. Burial 228, Zvejnieki.

Anthropomorphic and zoomorphic representations in burial context

The anthropomorphic and zoomorphic representations found at Zvejnieki are very rare and exceptional, so it is important to identify the imagery, and ascertain the location in the graves and the symbolic meaning of the objects. The number of art objects and the number of graves with such finds are small, and therefore our conclusions are mainly restricted to this particular burial ground - Zvejnieki.
The artistic representations have mainly been found in single graves; however, they were also present in two collective graves. All of the interred individuals accompanied by art objects had been laid in extended supine position, but their orientation varied. The graves or parts of them were ochre-strewn, with one exception - burial 228. Stone settings are represented only in the Late Mesolithic-Early Neolithic group of burials.

Three of the described burials - no. 162 (male), no. 271a (child) and no. 172 (child) - had been provided only with an art object, while all the other graves, in ad- 


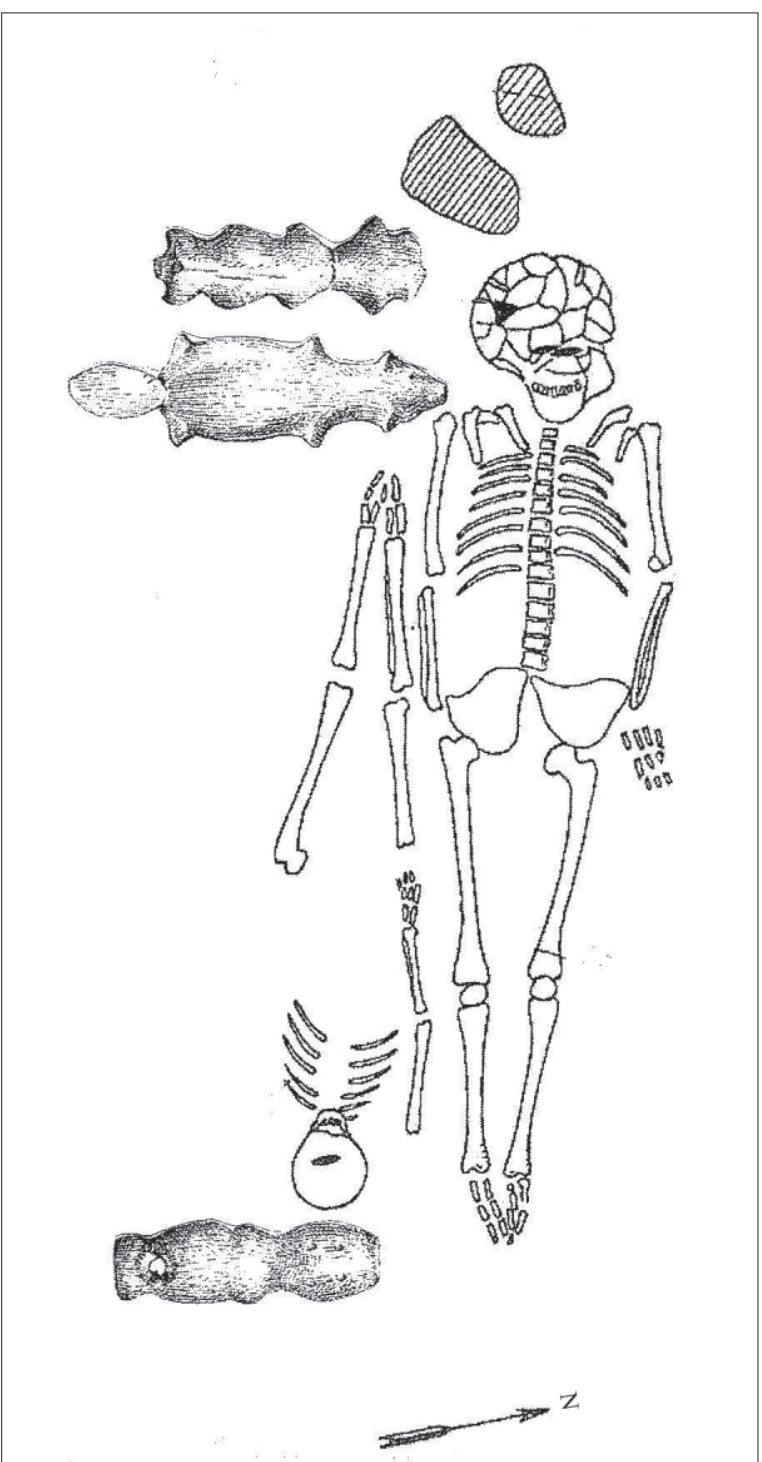

Fig. 13. Double burial, Valma (after Jaanits 1965, Fig. 6).

dition to artistic representations, contained rich grave goods in the form of tooth pendants, amber jewellery, bone, antler and stone grave goods (Table I).

The small, mobiliary zoomorphic and anthropomorphic objects found as grave goods at Zvejnieki burial ground include images of everything existing in nature at that time: figurines of birds, forest and aquatic animals, and human beings. It is obvious that all of these were very important in the life and death of the Stone Age hunter-gatherers.

As concerns the species represented by these art objects, bird images predominate (six items), with depictions of whole birds or heads; there are two elk head objects - staffs; a third staff shows the head of an otter (burial 271a). If we consider the small clay idol as anthropomorphic, then four human beings are represented in the art from Zvejnieki. The subject depicted by the single stone figurine remains undetermined.

\section{Zoomorphic depictions}

Bird images dominate at this burial ground. Six bird depictions have been found in five graves, from the earliest burials, dated to the beginning of the Late Mesolithic (burial 74), until the end of the Middle Neolithic (burial 228). The earliest figurine of a bird, made from wild boar tusk, is very schematic. Similar bird figurines from wild boar tusks have been found in the Late Mesolithic layer at the Osa settlement (Lubāns Lowland) (Zagorskis 1984). Some figurines depicting a bird's head and made from wild boar tusk have been found in Neolithic settlement layers at Eiṇi (Lubāns Lowland) and Kreiči (Lake Ludza basin) (Loze 2015, Fig. 17). Two bone figurines from graves at Zvejnieki likewise represent only heads of birds, and in one grave a bird with a two heads has been carved from an antler rod (burial 221). Well known are the small figurines representing swimming waterbirds (Tõrv et al. 2017). Such pieces have been found at the Riņnukalns settlement site by Lake Burtnieks, and on Stone Age sites and as stray finds in the Lubāns Lowland. All of these have drilled holes (one or even two) for attachment to the dress or to a necklace. A very carefully cut bird image made from sturgeon bone, depicting a bird in a flight, is unique (Fig. 17: 6).

Important is the location of the small bird figurine with burial 74: just above the head of this female burial. This may indicate a connection with some kind of death magic. Another explanation for the use of the figurines could be indicated by the two pieces placed with burial 228 (male): together with two human depictions, these were found in the neck area, below the chin, and could be part of a necklace.

Bird bones are relatively rare in graves, but the variety of such finds is quite impressive. Separate bones and pendants made from bird bones have been discovered in graves: these derive from mallard (Anas platyrhynchos), goosander (Mergus merganser) and red-breasted merganser (Mergus serrator). Burial 164 was distinguished by the presence of jay (Garrulus glandarius) wing bones (Mannermaa et al. 2007). An interesting deposit was found with a male burial (no. 153), where bones of mallard were unearthed next to the left elbow, while close to the right elbow there were a variety of duck bones. It is assumed that at least two complete birds were put in the grave. By contrast, there are very few bird bones in settlement deposits at Zvejnieki (Lõugas 2006). All of this shows the importance of bird images in the world view and burial traditions of the Stone Age people.

Elk figurines, very well known in the Stone Age art of the East Baltic, occur only in two graves in Zvejnieki: a 


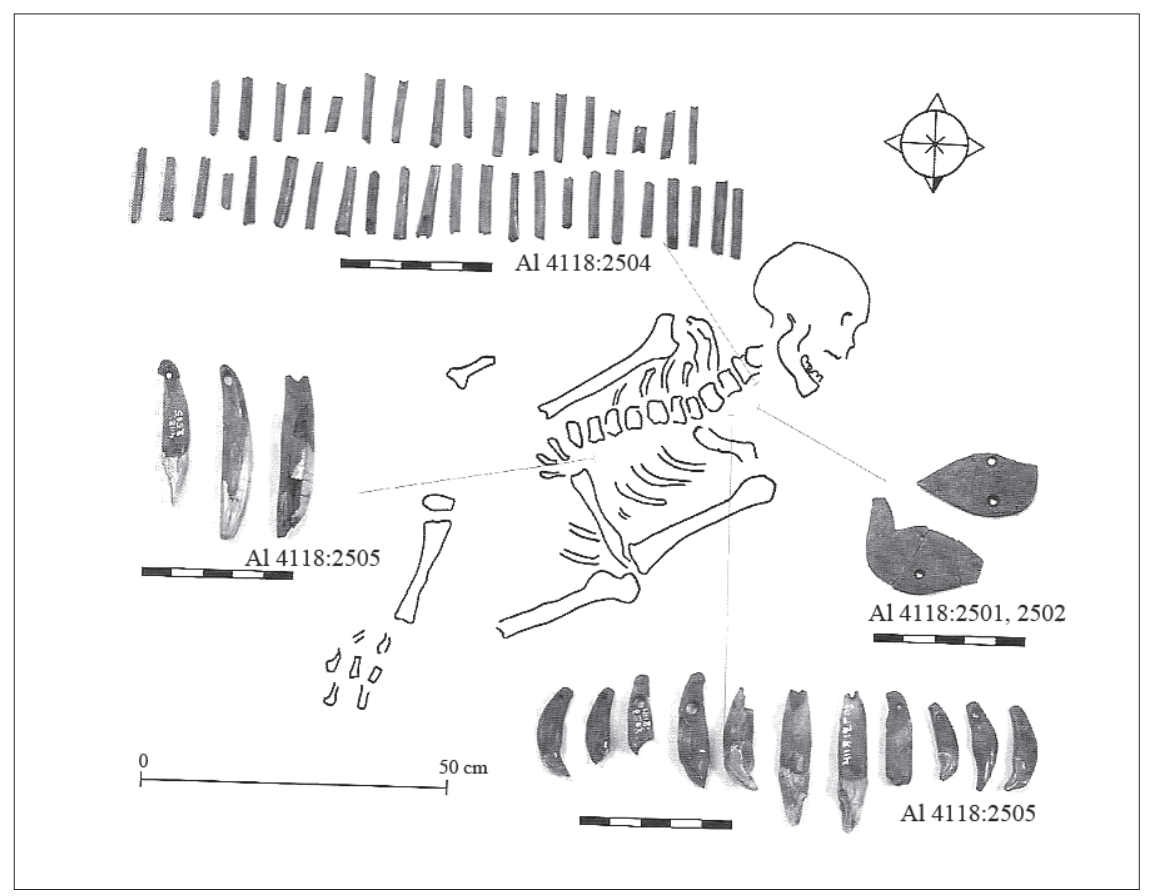

Fig. 14. Burial VIII, Tamula (after Kriiska et al. 2007, Fig. 9).

dagger with a schematically depicted elk head in a Late Mesolithic grave (burial 57) and an elk head staff (burial 277, Middle Neolithic). A similar staff, but depicting an aquatic animal, perhaps an otter, has been found with Middle Neolithic burial 271a. Otter (Lutra lutra) bones are known from the burial ground, and of course this animal lived in the area. The dagger with an elk head handle as well as both antler staffs were found in the graves by the legs and feet of the burials, differing in this regard from observations at other burial sites, for example Olenii Ostrov by Lake Onega (Gurina 1956), where elk head staffs have mainly been found in the upper part of grave - by the shoulders or hands of the buried individuals. Daggers with elk head representations are known from all periods of the Stone Age in Latvia - from the Late Mesolithic Osa settlement site in the Lubāns Lowland (Zagorskis 1984) as well from the Rinnnukalns site in the Lake Burtnieks area, dated to the end of the Middle Neolithic (Zagorska 2016). Two of the Zvejnieki staffs found in the graves (with burials 277 and 271a) differ from the rest by the oblique termination of the end of the staff (Fig. 16: 6, 7).

\section{Human figurines}

Anthropomorphic depictions are the most widely represented figurines in East Baltic art (Butrimas 2000). There are four human figurines from the graves at Zvejnieki, made in different styles and from different materials (antler, bone and clay).
The oldest is probably a female sculpture carved from an antler plate, which was found in a burial 172 , the disturbed grave of a child. It can be assumed that the idol was endowed with protective power and was provided for the small child buried here. The find is attributed to the Early Neolithic. The find and burial are not dated directly and even its attribution to a phase is based not on the presence of diagnostic Early Neolithic artefacts, but on a parallel with a find from a site with Early Neolithic artefacts (i.e. the assumption that this type of idol was only produced for a short period). Quite different are two other human figurines, represented only by heads and dated to the end of the Middle Neolithic. The first, made from an antler tine, and the second, made from sturgeon bone, are very schematic; they were used as part of a necklace, as clearly indicated by their location in the grave, and were associated with a male burial.

The last human depiction is an example of the widely known clay idols or so-called "convex-concave figurines" (Nunez 1986; Loze 1995; Butrimas 2000). It was found in a collective grave, no. 220-225, where five individuals were buried very close together. A small child (burial 224) had been laid between the chest area of burial 225 and the leg bones of burials 222 and 223, and the idol was found in the region of the skull fragments and ribs, so it is associated with the child. This grave dates from the Middle Neolithic period.

The graves containing art objects show quite a similar picture with regard to gender relations. Artistic representations were found with four female and three male

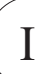

STONE AGE IN NORTHERN EUROPE: CHANGES IN LANDSCAPE, TECHNOLOGIES AND BELIEFS 


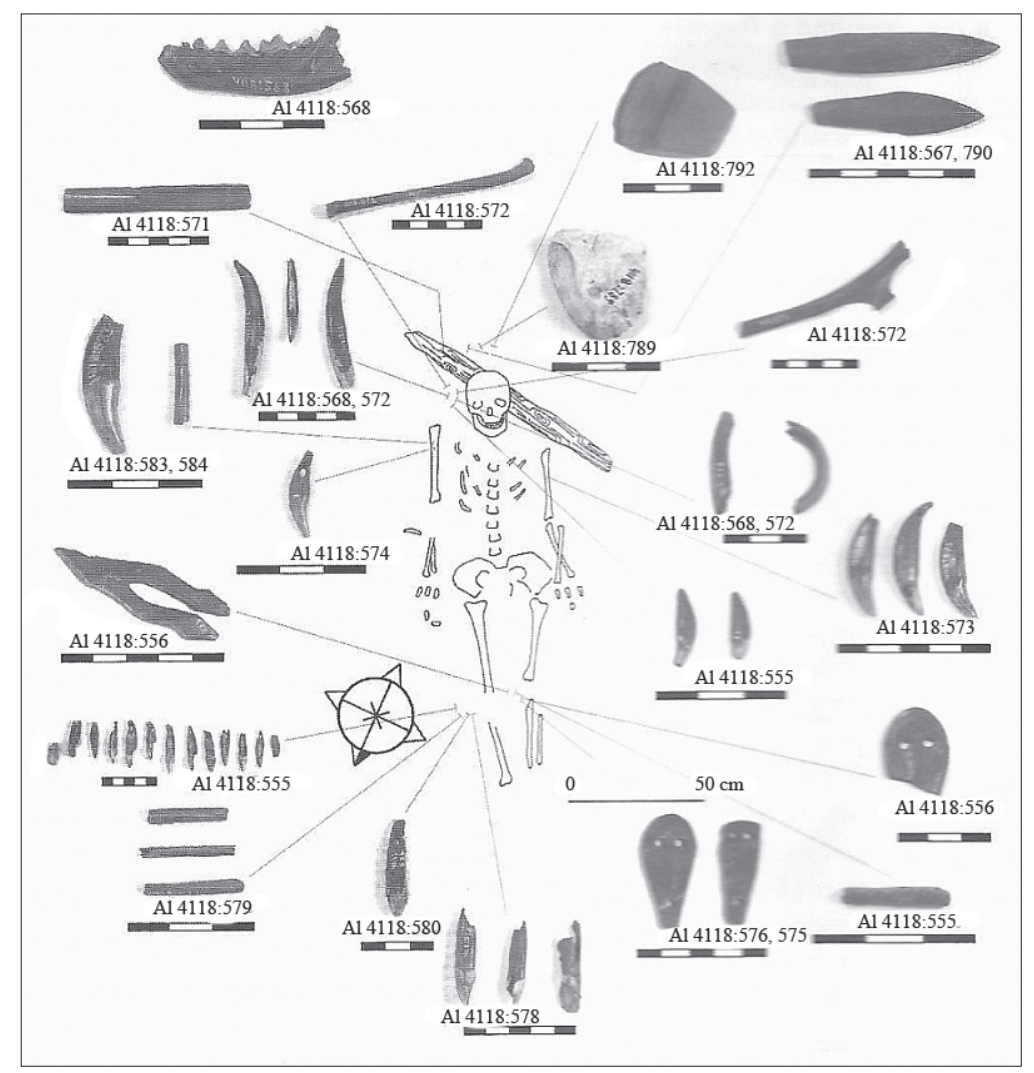

Fig. 15. Burial XIX, Tamula (after Kriiska et al. 2007, Fig. 10).

burials as well as four child burials (infans I, II), and one of the child burials (224) has been determined as male. So, we have four female and four male burials, as well as three child burials of undetermined sex that are provided with art objects. The situation is different if we look at these finds in chronological order. In the Late Mesolithic-Early Neolithic period all the individuals are female, with the exception of one undetermined burial (infans II). In the Middle Neolithic the individuals provided with art objects are mainly male (three males, one female and one undetermined infant).

We may mention as the most characteristic examples two burials from Zvejnieki. These include Mesolithic female burial 57, with a spearhead and bone staff in the form of an elk head, tooth pendants and a stone chisel as grave goods. The Neolithic male burial 228 had amber jewellery and a necklace containing four bone and antler figurines - birds and human beings - making it the richest burial in terms of art objects.

Perhaps these burials represent leaders or prominent members of the community. In very many cases the art objects have been provided for adolescents and small children, perhaps as idols with protective power. It has been described previously that child graves at Zvejnieki were arranged with great care, in all cases strewn with ochre and provided with grave goods (Zagorska et al. 2003).
The animal figurines from Zvejnieki, depicted in bone, antler and stone, indicate keen observation and perfect knowledge of the subject, which enabled the craftsmen to produce these true-to-life images. Some bird depictions and human figurines are more stylised. A frequent characteristic is the depiction of the heads only, this being the most essential part of the subject. In some cases the heads of bird figurines have been broken off, pointing to a very different burial tradition. The majority of the described figurines are covered with ochre, colouring them dark red. In characterising the zoomorphic and anthropomorphic figurines found at Zvejnieki burial ground, we may see a strong link between the ancient people and their environment, and an ability to reflect their surroundings, so important for hunterfisher-gatherers. Informative is an image among the petroglyphs at Cape Peri by Lake Onega. It shows a composition with an elk, an otter and a man in a row, touching and following each other (Savateev 1990).

The artistic representations from Zvejnieki burial ground shows that some of the art pieces were specially prepared for the buried individuals, whereas others are quite worn out, damaged or even broken and have long life histories. The data from Zvejnieki burial ground indicates that, whatever these art objects had been in their previous lives, in the burials they obtained a new dimension, becoming ritual objects. All this indicates the importance of figurines in ancient death rituals and 


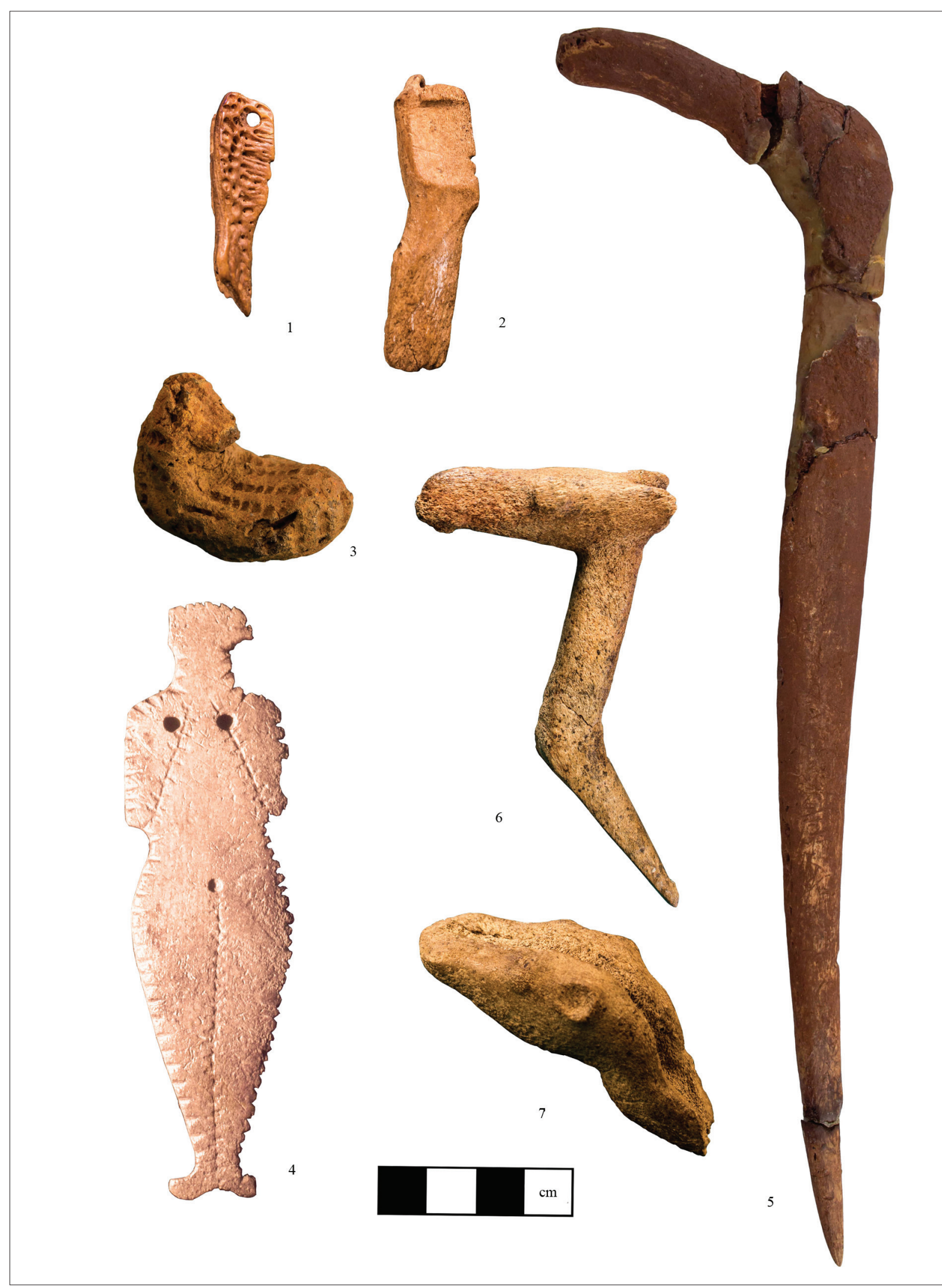

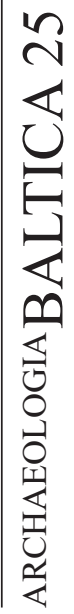

I

STONE AGE

IN NORTHERN

EUROPE:

CHANGES IN

LANDSCAPE,

TECHNOLOGIES

AND BELIEFS

Fig. 16. Artistic representations from Zvejnieki: 1, 2 - human heads, bone and antler, burial 228; 3 - clay idol, burial 224; 4 - female figurine on antler plaquette, burial 172; 5 - bone dagger/staff, burial 57; 6 - antler elk head staff, burial 277; 7 - antler staff with animal (otter?) head, burial 271a. 
shows the firm belief of the ancient inhabitants in life beyond the grave.

Of course, it is impossible to understand the real meaning of the images for the Stone Age people. We may only suggest some interpretations, based on archaeological and ethnohistorical data (Nunez 1995; Zvelebil 2003).

Also symbolic is the place in the landscape where the two habitation sites and the burial ground were located: the long gravel ridge some 4-7 $\mathrm{m}$ above the water level of Lake Burtnieks, by the mouth of a river, offering a wide and beautiful panorama of the surroundings and used for millennia. Such landscapes were also known in northern Europe and could be considered holy places in the cosmology of the Stone Age people (Zvelebil 1997; Butrimas 2012; Jonuks 2016).

\section{The chronology of}

the anthropomorphic and

zoomorphic images from Zvejnieki

and their significance within

the East Baltic region

Due to the uniform natural environment, the similarity of the economy and the common belief system, the hunter-gatherers throughout the northern European forest zone dealt in their artistic representations with three main subjects: animals, birds and human beings. These were depicted in petroglyphs, carved in bone, antler, wood, flint and stone, and also represented in amber and clay. Such figurines are more exceptional as finds in graves. Based on previous and newly obtained datings, we may examine them in a time perspective spanning several thousand years, from the Late Mesolithic to the end of the Middle Neolithic. The context of similar finds in the East Baltic and neighbouring regions may also be considered.

The artistic representations from the Late Mesolithic and Early Neolithic graves - the bird figurines and elk-head staff - are the oldest in the whole of the East Baltic (Table II). At Spiginas and Donkalnis in Lithuania there are Mesolithic-Early Neolithic graves richly strewn with ochre and adorned with tooth pendant jewellery, but they are few in number, and no art objects have been found in these graves (Butrimas 2012; Butrimas 2016). Of course, there are also some art objects from this period from a Late Mesolithic settlement site Osa in Latvia and also pieces recovered as stray finds - a female figurine in antler and a waterfowl depiction from the River Pärnu, Estonia, both dated to the period $6200-5900 \mathrm{cal}$. BC; in addition, there is the famous figurine of a viper, found as a stray find at Torrvala by the River Narva. It is supposed that some of these items could derive from burials (Jonuks 2013; Jonuks 2016).

An impressive find from the Early Neolithic is a female figurine carved from an antler plaquette, found in a child's grave. It cannot be dated with certainty, but in accordance with the style of decoration and a similar find at Lake Ladoga, it may be ascribed to Early Neolithic. Thus, female depictions in East Baltic art are important in the Late Mesolithic-Early Neolithic period, occurring in graves and as stray finds (Zvejnieki and the River Pärnu find).

The Middle Neolithic graves are temporally more compact - all are dated approximately 4000-3300 cal BC. Only burial 277 , in a collective grave, is potentially earlier, c. 4400-3800 cal BC, marking the beginning of this period (Fig. 2; Table II). This period is characterised by more realistic anthropomorphic representations - rounded antler or bone figurines representing part of an animal (the head) or the whole body. Mention should first be made of the antler staffs occurring with male burial (no. 277) and the burial of a small child (no. 271a), which are realistic head depictions, emphasising all the characteristic features of the animals. One may also include in this group the unique figurine of a bird made from sturgeon bone (burial 228). Depicted in the same realistic manner are animals from a double grave on the Valma site - a Middle Neolithic settlement by Lake Võrtsjärv in Estonia. Here, a female and male were buried in a double grave in opposed orientation (Jaanits 1965). The grave goods were two bone figurines under the male's head and one amber figurine by the female's head (Fig. 13). One of the figurines shows a beaver in a swimming position, while the other is more fragmentary. An amber figurine with a female burial is now likewise interpreted as depicting a beaver (Ots 2010).

Very popular in Stone Age art are small, flat figurines of swimming waterbirds, generally carved from bone, with a broken head and a hole for attachment. Some examples in amber are also known. In Latvia they have mainly been found on settlement sites and as stray finds: at Nainiekste, Lagaža, Abora I, Leimanišķi, Malmuta and Riņņukalns. Some similar silhouettes are carved at the top of bone knife handles from the Lake Lubāns area. Only one such figurine has been found at Zvejnieki: this is from burial 228, part of a necklace under the chin of the buried individual. In Estonia, on the Tamula settlement, where burials were also found, the picture is quite different (Jaanits 1957; Tõrv et al. 2017). The small waterfowl figurines here were all clearly connected with burials: one was in a child's grave (no. VII), two were in the grave of an adult female (no. X) and two came from the grave of an adult 


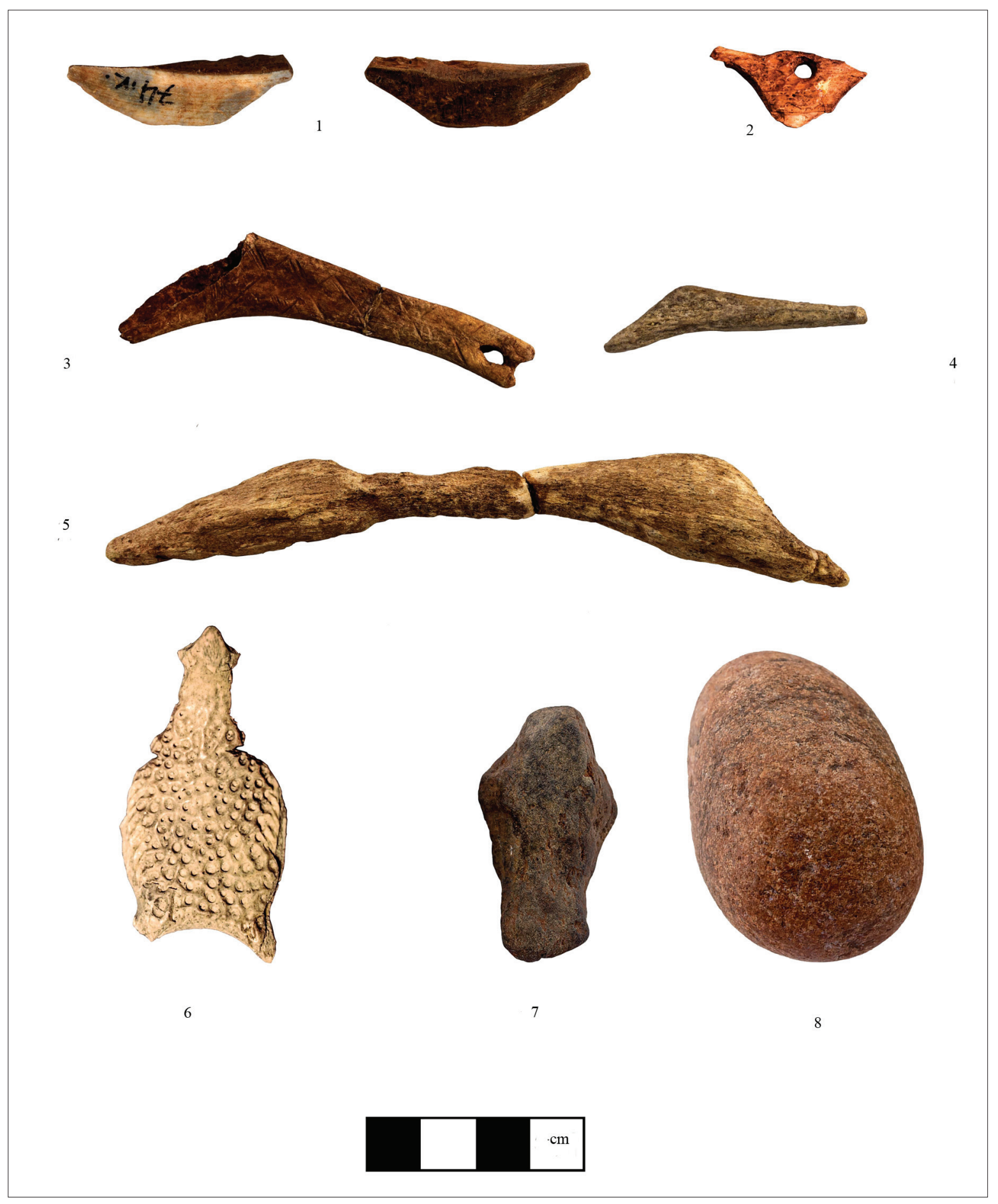

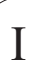

STONE AGE IN NORTHERN EUROPE:

CHANGES IN LANDSCAPE, TECHNOLOGIES AND BELIEFS

Fig. 17. Artistic representations from Zvejnieki: 1 - bird figurine from wild boar tusk - burial 74; 2 - bird figurine, bone, burial 228; 3 - bird's head pendant, bone, burial 100; 4 - bird's head figurine, bone, burial 162; 5 - two-headed bird figurine, antler, burial 221; 6 - bird figurine, bone, burial 228; 7 - unidentified image, stone, burial 121; 8 - pebble, burial 121.

male (no. XIX). The figurine in the child's grave was found on the right collarbone; the one in the woman's grave was under the skull, and the one in the man's grave was under the chin of the burial together with cylindrical bone beads, forming a necklace (Figs. 14, 15). The Zvejnieki and Tamula burials are from the same period - the end of the Middle Neolithic (Fig.
2) - and clearly show the importance of the bird in Stone Age burial practices. It could serve as a protective amulet, and perhaps also as a messenger between life and death.

Absent at Zvejnieki are snake depictions, as represented on the Abora I site in the Lubāns Lowland by a figurine in amber from the grave of a small child (Loze 
2008, Plate 49:5). Snake depictions in bone are known from the settlement site and graves at Tamula, and from the Olenii Ostrov cemetery (Jaanits 1957; 1965; Gurina 1956). A "clay snake" has been found at the Hietiniemi site, Finland (Edgren 1966). Snake motifs are rare, but they occur in all periods of the Stone Age.

Characteristic of the Middle Neolithic and later are bent idols made in clay, such as the one found with a burial (no. 224) at Zvejnieki. Similar figurines are known from Latvian sites, but they mainly occur on settlement sites in Finland, such as Madeneva Riukjärvi, Hietaniemi and others (Loze 1995).

Two figurines showing human heads in bone and antler, found with burial 228, dated to the end of Middle Neolithic (Fig. 15:4,5), are made in a style very widely represented in the East Baltic. They depict elongated, quite schematic human faces with emphasized eyebrows, a projecting nose, hollows on both sides of the nose and a long neck (Butrimas 2000, 23-26; Iršènas 2010, Fig. 5). Similar head depictions in bone occur at Tamula, found in the knee area of female burial VIII and on the settlement site, with the difference that the eyes and mouth are depicted by drilled holes (Jaanits 1957; Kriiska et al. 2007). Researchers also mention the great similarity of human images in bone to head depictions in amber (Butrimas 2000; Iršènas 2010). A very special grave at Kukkarkoski burial ground (southern Finland), no. 1a, was intensively ochre-strewn, with rich grave goods and a depiction of a human head in amber as a pendant. The burial is similar in date to the Middle Neolithic graves at Zvejnieki: $4040-3350 \mathrm{cal} \mathrm{BC}$ (Torvinen 1978; Ahola 2016 'carbonised wood from base of grave fill', Hel-832, 4890 \pm 150 BP). Similar amber figurines of human heads have been recovered as stray finds close to a Finnish Neolithic rock art site in the Lake Saimaa region (Lahelma 2008, 133). There is also an analogue from Latvia - an amber head from the Romi-Kalnini site, close to Riga (Vankina 1983; Iršènas 2010).

The tradition of depicting faces of this kind in bone continued even later. Thus, at the settlement site of Kretuonas IC, on the eastern shore of Lake Kretuonas in Lithuania, human bones were found together with figurines in special grave pits. These were dated to the Early Bronze Age and are described as images of ancestors (Girininkas 2009, Fig. 194: 9, 10; Girininkas 2016). It is obvious that anthropomorphic representations dominate in East Baltic art at the end of the Middle Neolithic, as well as in the Late Neolithic and later.

\section{Conclusions}

In the period discussed here $(6000-3300$ cal BC), two cultural traditions may be traced throughout the East Baltic: the Narva Culture, continuing the indigenous burial practices, and the incoming Comb Ware Culture, characterised by collective graves with a rich inventory and certain distinctive burial practices, which was, however, gradually assimilated into the indigenous milieu. As already pointed out by researchers of artistic practices (Jan Fast), cultural influences and ancient rituals, also reflected in the ancient artistic representations, spread across the boundaries of particular cultures, coming under various influences and being transformed. The ancient zoomorphic and anthropomorphic representations appear strictly rooted in observations of the environment, in the characteristic way of life of the fisher-hunter communities, and in their burial practices and beliefs concerning life beyond the grave.

\section{Acknowledgments}

The article has been written in the frame of the project "Prehistoric art: ritual, context and symbolism", financed by the Research Council of Lithuania, project No. MIP-036/2015. The drawings illustrating the Zvejnieki burials and artefacts are by Marta Jāṇkalnina, and the colour photos are by Līga Palma. English language correction has been undertaken by Valdis Bērziñš.

\section{References}

AHOLA, M., 2015. Tracing Neolithic Funerary Practices from Finnish Ochre Graves - a case study from Kukkarkoski Comb Ware burial ground. Thanatos, 42, 23-41.

BRONK RAMSEY, C., 2009. Bayesian analysis of radiocarbon dates. Radiocarbon, 51, 337-360.

BUTRIMAS, A., 2000. Human figurines in eastern Baltic prehistoric art. Acta Academiae Artium Vilnensis, 20, 7-29.

BUTRIMAS, A., 2012. Donkalnio ir Spigino mezolito - neolito kapinynai. Seniausi laidojimo paminklai Lietuvoje. Vilnius: Vilniaus dailes akademijos leidykla.

BUTRIMAS, A., 2016. Biržulis lake islands Donkalnis and Spiginas Mesolithic cemeteries (West Lithuania). In: J.M., GRÜNBERG, B., GRAMSCH, L., LARSSON, J., ORSCHIEDT, H., MELLER, eds. International conference Halle (Saale), Germany, 18-21 September. -, Tagungen des Landesmuseums für Vorgeschichte Halle, 13/1. Halle (Saale): Landesmuseums für Vorgeschichte Halle, 193-217.

DENIRO, M.J., 1985. Postmortem preservation and alteration of in vivo bone collagen isotope ratios in relation to palaeodietary reconstruction. Nature, 317, 806-809.

ERIKSSON, G., 2006. Stable isotope analysis of human and faunal remains from Zvejnieki. In: L., LARSSON, I., ZAGORSKA, eds. Back to the Origin. New Research in the Mesolithic-Neolithic Zvejnieki Cemetery \& Environment, Northern Latvia. Acta Archaeologica Lundensia Series 
in 8, 52. Stockholm: Almqvist \& Wiksell international, $183-216$

ERIKSSON, G., LÕUGAS, L., ZAGORSKA, I., 2003. Stone Age hunter-fisher-gatherers at Zvejnieki, northern Latvia: radiocarbon, stable isotope and archaeozoology data. Before Farming, 2003/1 (2), 1-26.

EDGREN, T., 1966. Einige neue Funde von kammkeramischen Vogelbildern und Tierskulpturen aus Ton. Finkst Museum, 73, 8-24.

FERNANDES, R., MILLARD, A.R., BRABEC, M., NADEAU, M.J., GROOTES, P., 2014. Food reconstruction using isotopic transferred signals (FRUITS): a Bayesian model for diet reconstruction. PLOS ONE, 9(2), (https:// doi.org/10.1371/journal.pone.0087436)

GIRININKAS, A., 2009. Akmens amžius . Lietuvos Archeologija I. Vilnius: Versus Aureus.

GIRININKAS, A., 2016. The Early Bronze Age cemetery in East Lithuania. In: G., Zabiela, Z., Baubonis, E., Marcinkevičiute, eds. A hundred years of archaeological discoveries in Lithuania. Vilnius: Society of Lithuanian archaeology, 110-119.

GURINA, N.N., 1956. Oleneostrovskii mogil'nik. Materialy i issledovaniia po arkhelogii SSSR, 47. Moskva - Leningrad.

IRŠÉNAS, M., 2000. Elk figurines in the Stone Age art of the Baltic area. Acta Academiae Artium Vilnensis, 20, 77-85.

IRŠĖNAS, M., 2006. Anthropomorphic and zoomorphic figurines from the Zvejnieki burial ground in the context of the Baltic area. Statistical regularities or exceptional cases? In: L., LARSSON, I., ZAGORSKA, eds. Back to the Origin. New Research in the Mesolithic-Neolithic Zvejnieki Cemetery \& Environment, Northern Latvia. Acta Archaeologica Lundensia Series in 8, 52. Stockholm: Almqvist \& Wiksell international, 301-308.

IRŠĖNAS, M., 2010. Anthropomorphic and zoomorphic Stone Age art in Lithuania, and its archaeological cultural context. Archaeologia Baltica, 13, 175-190.

JAANITS, L., 1957. Neue Gräberfunde auf dem spätneolithischen Wohnplatz Tamula in Estland. Suomen Muinaismuistoyhdistyksen Aikakauskirja - Finska Fornminnesföreningens Tidskrift, 58, 80-100.

JAANITS, L., 1965. Über die Ergebnisse der Steinzeitforschung in Sowjetestland. Finskt Museum, 72, 5-45.

JONUKS, T., 2013. An antler object from the Pärnu river an axe, a god or a decoy? Muinasaja Teadus, 19, 225-246.

JONUKS, T., 2016. A mesolithic human figurine from river Pärnu, south-west Estonia: a century-old puzzle of idols, goddesses and ancestral symbols. Estonian journal of Archaeology, 20 (2), 111-127.

KRIISKA, A., LÕUGAS, L., LÕHMUS, M., MANNERMAA, K., JOHANSON, K., 2007. New AMS dates from Estonian Stone Age burial sites. Estonian Journal of Archaeology, 11 (2), 83-121.

LAHELMA, A., 2008. A touch of red. Archaeological and ethnographic approaches to interpreting Finnish rock paintings. Helsinki: The Finnish antiquarian society.

LOZE, I., 1995. Clay figural art in the forest belt of Neolithic eastern Europe. Archaeologica Baltica, 1, 33-42.

LOZE, I., 2008. Lubāna ezera mitrāja neolìta dzintars. Rīga: Latvijas vēstures institūta apgāds.

LOZE, I., 2015. Lubāna mitrāja apdzīvotība akmens laikmetā. Rēzeknes novada mezolīta un neolìta apmetnes. Rīga-Rēzekne: Rēzeknes Augstskola.

LÕUGAS, L., 2006. Animals as subsistence and bones as raw material for settlers of prehistoric Zvejnieki. In: L., LARSSON, I., ZAGORSKA, eds. Back to the Origin. New
Research in the Mesolithic-Neolithic Zvejnieki Cemetery \& Environment, Northern Latvia. Acta Archaeologica Lundensia Series in 8, 52. Stockholm: Almqvist \& Wiksell international, 75-90.

MANNERMAA, K., ZAGORSKA, I., JUNGNER, H., ZARINA, G., 2007. New radiocarbon dates of human and bird bones from Zvejnieki Stone Age burial ground in northern Latvia. Before farming, 1, 2-17.

MANNERMAA, K., 2008. Birds and burials at Ajvide (Gotland, Sweden) and Zvejnieki (Latvia) about 8000-3900 BP. Journal of anthropological archaeology, 27, 201-225. MEADOWS, J., BĒRZIN̦Š, V., LÜBKE, H., SCHMÖLCKE, U., ZAGORSKA, I., ZARIN̦A, G., 2016. Dietary freshwater reservoir effects and the radiocarbon ages of prehistoric human bones from Zvejnieki, Latvia. Journal of archaeological science: reports, 6, 678-689.

MEADOWS, J., BĒRZIN̦Š, V., LEGZDIN̦A, D., LÜBKE, H., SCHMÖLCKE, U., ZAGORSKA, I., ZARIN̦A, G., 2018. Stone Age subsistence strategies at lake Burtnieks, Latvia. Journal of archaeological science: reports, 17, 992-1006.

MIETTINEN, T., 1965. En idol från Hietaniemi i Luopioinen. Finkst Museum, 74, 34-44.

NADEAU, M.J., GROOTES, P.M., SCHLEICHER, M., HASSELBERG, P., RIECK, A., BITTERLING, M., 1998. Sample throughput and data quality at the Leibniz-Labor AMS facility. Radiocarbon, 40 (1), 239-45.

NUNEZ, M.G., 1986. Clay figurines from the Aland islands and mainland Finland. Fennoscandia archaeologica, 3, $17-34$.

NUNEZ, M., 1995. Reflections on Finnish rock art and ethnohistorical data. Fennoscandia archaeologica, 12, 123 135.

NILSSON STUTZ, L., LARSSON, L., ZAGORSKA, I., 2013. The persistent presence of the dead: the significance of place and time revealed by the recent excavations at the hunter-gatherer cemetery at Zvejnieki (Latvia). Antiquity, 87, 1016-1029.

OTS, M., 2010. Loomakujukesed Valma keskneoliitilises kaksikmatuses. Muinasaja teadus, 21, 11-22.

REIMER, P.J., BARD, E., BAYLISS, A., BECK, J.W., BLACKWELL, P.G., BRONK RAMSEY, C., BUCK, C.E., CHENG, H., EDWARDS, R.L., FRIEDRICH, M., GROOTES, P.M., GUILDERSON, T.P., HAFLIDASON, H., HAJDAS, I., HATTÉ, C., HEATON, T.J., HOFFMANN, D.L., HOGG, A.G., HUGHEN, K.A., KAISER, K.F., KROMER, B., MANNING, S.W., NIU, M., REIMER, R.W., RICHARDS, D.A., SCOTT, E.M., SOUTHON, J.R., STAFF, R.A., TURNEY, C.S. M., VAN DER PLICHT, J., 2013. IntCal13 and Marine13 Radiocarbon Age Calibration Curves 0-50,000 Years cal BP. Radiocarbon, 55 (4), 1869-1887.

SAVATEEV, J.A., 1990. Kamennaja letopis Karelii. Petroglifi Onežskovo ozera i Belovo morja. Petrozavodsk.

SIEVERS, C.G., 1875. Ein normännisches Schiffsgrab bei Ronnerburg und die Ausgrabungen des Rinnehügels am Burtneck-See. Verhandlungen der Berliner Gesellschaft für Anthroplogie, Ethnologie und Urgeschichte. Zeitschrift für Ethnologie, 7 (2), 214-223.

STUDZICKAJA, S.V., 1994. Osobennosti duhovnoi kulturi volosovskih plemen. Trudi gosudarstvennovo istoricheskovo muzeja, 85, 59-77.

TIMOFEEV, V.I., 1993. Pamjatniki mezolita i neolīta reǵiona Peterburga $\mathrm{i}$ ih mesto $\mathrm{v}$ sisteme kultur kamennovo veka Baltiskovo reǵiona. In: V.M., MASSON, E.N., NOSOV,

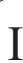

STONE AGE IN NORTHERN EUROPE: CHANGES IN LANDSCAPE, TECHNOLOGIES AND BELIEFS 
E.A., RJABININ, eds. Drevnosti severo-zapada. SanktPeterburg, 8-34.

TÕRV, M., 2016. Persistent Practices. A multi-disciplinary study of hunter-gatherer mortuary remains from c. 6500 2600 cal. BC, Estonia. Dissertationes archaeologiae Universitatis Tartuensis 5, Tartu: Tartu Ulikooli Kirjastus.

TÕRV, M., LÜBKE, H., MEADOWS, J., ZAGORSKA, I., BĒRZIN̦Š, V., 2017. Soul carriers to the afterlife? The context and meaning of the bird figurines from Rinnukalns. In: B.V., ERIKSEN, ed. Interaktion ohne Grenzen. Beispiele archaeologischen Forschungen am beginn des 21 Jahrhundert. Band I. Schleswig, 49-61.

TORVINEN, M., 1978. Liedon Kukkarkosken kivikautinen kalmisto. Suomen Museo, 85, 37-79.

VANKINA, L., 1983. Jantarnie amuleti kamennovo veka iz okrestnostei g. Rigi. Iziskanija po mezolitu i neolītu SSSR. AN SSSR, Institut Arheologii, 135-137.

ZAGORSKA, I., 1997. Par kādu retu akmens laikmeta apbedīšanas tradīciju. Arheologija un etnogrāfija, 19, $42-50$.

ZAGORSKA, I., 2000. The art from Zvejnieki burial ground, Latvia. Acta Academiae Artium Vilnensis, 20, 79-92.

ZAGORSKA, I., GERNHARDS, G., ZARIN̦A, G., 2003. Burial traditions in the East Baltic Mesolithic. In: L., LARSSON, H., KINDGREN, K., KNUTSSON, D., LOEFFLER, A., ÅKERLUND, eds. Mesolithic on the Move. Oxford: Oxbow books, 558-562.

ZAGORSKA, I., LARSSON, L., 1994. New data on the chronology of the Zvejnieki Stone Age cemetery. Mesolithic miscellany, 15 (2), 3-10.

ZAGORSKA, I., 2016. Mesolithic burial traditions in Latvia. A case study from Zvejnieki burial ground. In: J.M., GRÜNBERG, B., GRAMSCH, L., LARSSON, J., ORSCHIEDT, H., MELLER, eds. International conference Halle (Saale), Germany, 18-21 September. Tagungen des Landesmuseums für Vorgeschichte Halle, 13/1, Halle (Saale): Landesmuseums für Vorgeschichte Halle, 225-240.

ZAGORSKIS, F., 1973. Das spätmesolithikum in Lettland. In: S.K., KOZŁOWSKI, ed. The Mesolithic in Europe. Warsaw: Warsaw University press, 651-669.

ZAGORSKIS, F., 1983. Kostjanaja i rogovaja skulptura iz mogilnika Zvejnieki. Iziskanija po mezolitu i neolitu SSSR. AN SSSR, Institut Arheologii, 138-142.

ZAGORSKIS, F., 1987. Zvejnieku akmens laikmeta kapulauks. Rīga: Zinātne.

ZAGORSKIS, F., 2004. Zvejnieki (Northern Latvia) Stone Age cemetery. British Archaeological Reports 1292. Oxford: Archaeopress.

ZHULNIKOV, A., KASHINA, E., 2010. Obraz ptitsy v iskusstve neolita - eneolits lesnoi zony vostochnoi Evropy. Rossiiskaia arkheologiia, 2, 5-7.

ZVELEBIL, M., 1997. Hunter-gatherer ritual landscapes: spatial organisation, social structure and ideology among hunter-gatherers of Northern Europe and Western Siberia. Analecta Praehistorica Leidensia, 29, 33-50.

ZVELEBIL, M., 2003. People behind the lithics. Social life and social conditions of Mesolithic communities in temperate Europe. In: L., BEVAN, J., MOORE, eds. Peopling the Mesolithic in a northern environment. BAR International Series 1157. Oxford: Archaeopress, 1-26.
Ilga Zagorska

Latvian University, Institute of History of Latvia

Kalpaka bulv.4, Riga LV, 1050, Latvia

E-mail: ilga.zagorska@gmail.com

John Meadows

Leibnic Laboratory for Radiometric Dating and Stable Isotop Research, Christian-Albrechts Univeristy, Kiel ax - Eyth Str. 11-13, D-24118, Kiel, Germany

E-mail: john.meadows@zbsa.eu

Marius Iršènas

Institute of Art Research

Vilnius Academy of Arts

Dominikonų g. 15, LT-01131 Vilnius, Lithuania

E-mail: marius.irsenas@vda.lt_

\section{NAUJI ZVEJNIEKŲ \\ KAPINYNO KAPU SU \\ ANTROPOMORFINIAIS IR \\ ZOOMORFINIO MENO \\ DIRB IN IAIS \\ RADIOKARBONINIS \\ DATAVIMAS}

\section{ILGA ZAGORSKA, JOHN MEADOWS, MARIUS IRŠE்NAS}

\section{Santrauka}

Straipsnyje pristatomi naujausi radiokarboniniai duomenys iš Zvejniekų akmens amžiaus kapinyno (Šiaurès Latvija) kapu (1 pav.), kuriuose rasta žmones ir gyvūnus vaizduojančių amuletų ir skulptūrèlių. Naujausi datavimai, atlikti Kylio laboratorijoje, rodo, kad kapai, kuriuose rasti meno objektai, datuojami vélyvuoju mezolitu - vèlyvuoju neolitu (2 pav.; 2 lentelè). Kapu, kuriuose rasta antropomorfinių ir zoomorfinių dirbinių, nèra daug. Tai kapai nr. 57, 74, 100, 121, 162, 172, 221, 224, 228, 271a, 277 (3-15 pav.; 1 lentelè). Vaizduojamojo meno dirbinius daugiausia sudaro gyvūnų - briedžiu, gyvačių, ịvairių rūšių paukščių, meškų ir ūdros vaizdai. Antropomorfiniai dirbiniai vaizduoja moteriškos lyties atstoves, embrionus, žmonių veidus $(16,17$ pav.). Dirbiniai buvo gaminti iš gyvūnų ragų, dantų, kaulų, molio. 